DOEIEM-0564

\title{
Tanks \\ Focus Area Annual Report
}
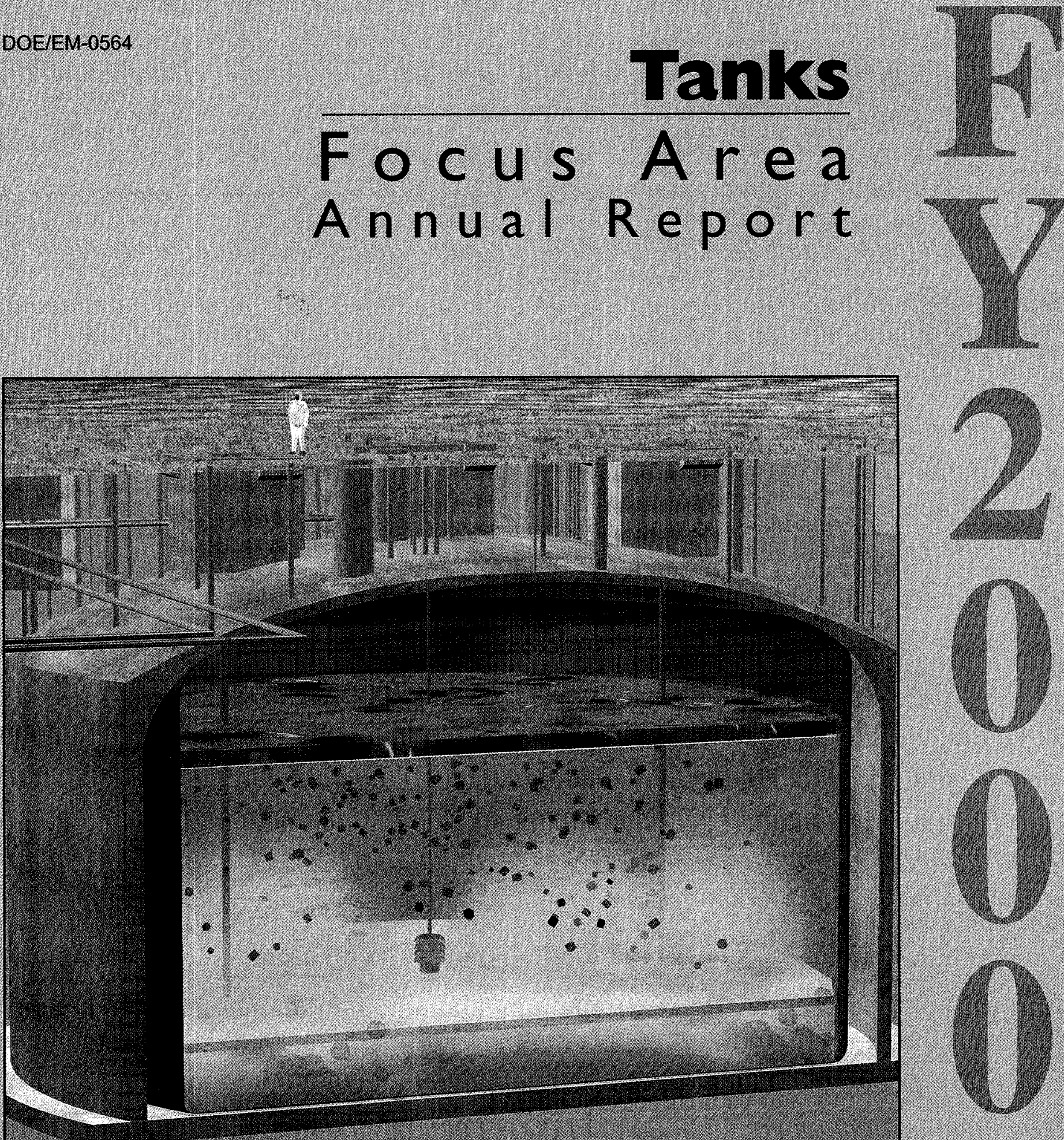

\section{Delivering technical solutions for radioactive waste tank remediation}

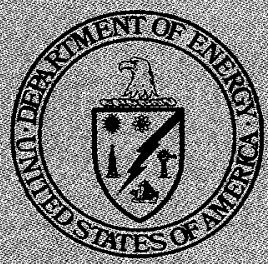

U.S. Department of Energy

Office of Envirommental Management

Office of Science and Technology 


\section{Contents}

Program Message

Background 2

Vision, Mission, and Goals ................................. 3

Process Steps.....................................................4

Management and Organization …….................6

Fiscal Year 2000 Accomplishments......................8

Idaho National Engineering and

Environmental Laboratory .8

Hanford Site.

Oak Ridge Reservation.

Savannah River Site .......................................... 14

West Valley Demonstration Project ...............16

Innovative Technology Summary Reports...... 18

Fiscal Year 2000 Project Summary ....................... 19

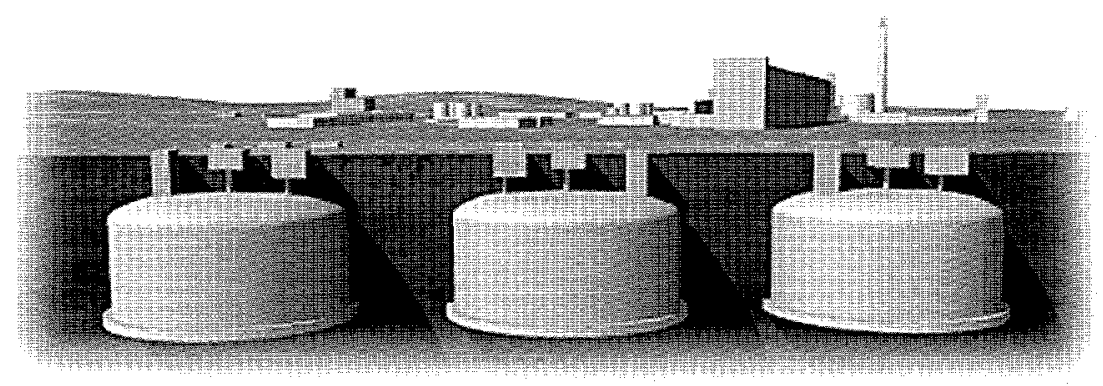




\section{DISCLAIMER}

This report was prepared as an account of work sponsored by an agency of the United States Government. Neither the United States Government nor any agency thereof, nor any of their employees, make any warranty, express or implied, or assumes any legal liability or responsibility for the accuracy, completeness, or usefulness of any information, apparatus, product, or process disclosed, or represents that its use would not infringe privately owned rights. Reference herein to any specific commercial product, process, or service by trade name, trademark, manufacturer, or otherwise does not necessarily constitute or imply its endorsement, recommendation, or favoring by the United States Government or any agency thereof. The views and opinions of authors expressed herein do not necessarily state or reflect those of the United States Government or any agency thereof. 


\section{DISCLAIMER}

Portions of this document may be illegible in electronic image products. Images are produced from the best available original document. 


\section{Department of Energy \\ Richland Operations Office \\ P.O. Box 550 \\ Richland, Washington 99352}

November 15,2000

\section{Subject: Tanks Focus Area (TFA) Program Message}

Since its inception in 1994, the TFA has enabled the ongoing development and implementation of approximately 100 technologies, accounting for approximately 100 deployments. The TFA is pleased to report continued accomplishments in fiscal year (FY) 2000 with a total of 24 deployments and 8 demonstrations. In addition to contributing to significant reductions in risk and schedule, the TFA estimates a net cost savings (or avoidance) of approximately $\$ 250$ million to date and anticipates the savings of billions of dollars in the future through deployment of existing TFA technologies and data.

TFA's success in implementation of new technical solutions is due in large part to close interactions with cleanup program managers, which have been greatly facilitated by the TFA Technology Integration Managers. In addition, under the Focus Area-Centered Approach, the valued expertise of the Crosscutting Programs has contributed further to technical accomplishments at the sites. This expertise, along with the extensive technical expertise provided through the TFA Technical Advisory Group, resulted in numerous requests for technical assistance in FY 2000, including the following notable examples:

- Savannah River Site-TFA provided direct management of the Salt Processing Project Research and Development effort including revision of technology roadmaps, development of technology downselection criteria, and preparation of a comprehensive R\&D Program Plan, in addition to direct project management of the technology development activities.

- Idaho National Engineering and Environmental Laboratory-TFA conducted three independent reviews to evaluate treatment options for the site's tank-related wastes, investigate the technical validity of an externally proposed treatment option, and provide technical recommendations in development of a Direct Vitrification Roadmap for Sodium-Bearing Waste.

- Fernald Environmental Management Project-TFA conducted an independent review to evaluate design documents related to waste handling and retrieval technology for remediation of silos at the site.

TFA continues to measure its success through the development, delivery, and deployment of integrated technical solutions and the provision of critically needed technical assistance. TFA looks forward to continued close interaction with site users to develop technical solutions that will reduce risk, save cost, and shorten cleanup schedules. As a provider of near-term baseline solutions and longer-term strategic solutions, TFA will continue to leverage national and international resources to assist sites in solving their toughest cleanup problems.

Thank you for your continued support of the TFA!

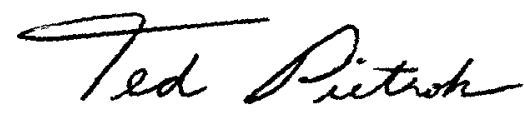

Ted Pietrok, Program Lead

Tanks Focus Area 


\section{The Tanks Focus Area Works With Users to ImPlement Technical Solutions to Sites' Needs}

\section{Technical solutions working to effect tank cleanup}

The U.S. Department of Energy (DOE)

continues to face a major radioactive waste tank remediation effort with tanks

containing hazardous and radioactive waste resulting from the production of nuclear materials. With some 90 million gallons of waste in the form of solid, sludge, liquid, and gas stored in 287 tanks across the DOE complex, containing approximately

650 million curies, radioactive waste storage tank remediation is the nation's highest cleanup priority.

Differing waste types and unique technical issues require specialized science and technology to achieve tank cleanup in an environmentally acceptable manner. Some of the waste has been stored for over 50 years in tanks that have exceeded their design lives. The challenge is to characterize and maintain these contents in a safe condition and continue to remediate and close each tank to minimize the risks of waste migration and exposure to workers, the public, and the environment.

In 1994, the DOE's Office of Environmental Management (EM) created a group of integrated, multiorganizational teams focusing on specific areas of the EM cleanup mission. These teams have evolved into five focus areas managed within EM's Office of Science and Technology (OST):

- Tanks Focus Area (TFA)

- Deactivation and Decommissioning Focus Area

- Nuclear Materials Focus Area

- Subsurface Contaminants Focus Area

- Transuranic and Mixed Waste Focus Area

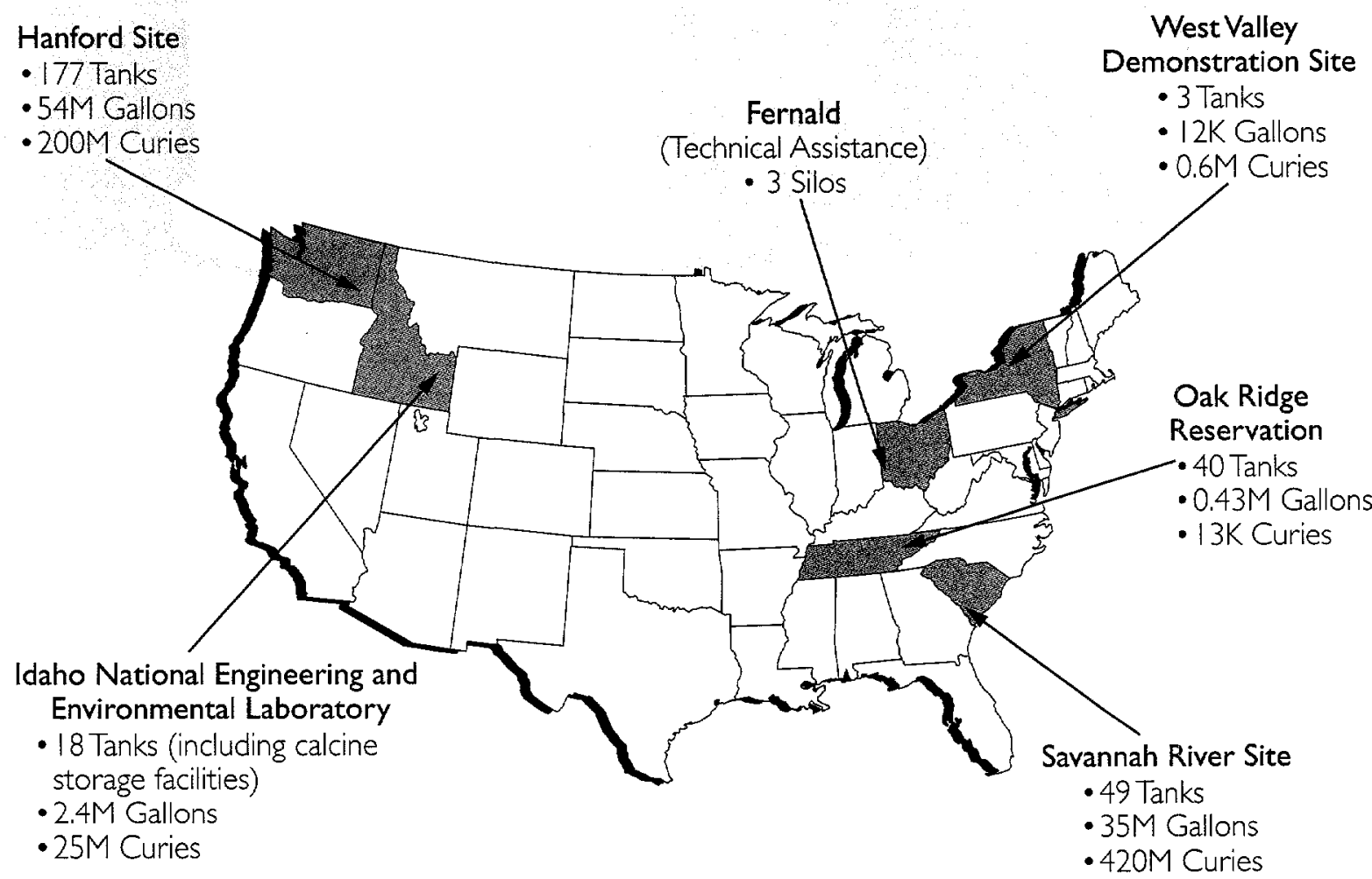




\section{The Tanks Focus Area Vision- Enable Tank Cleanup at DOE Sites}

The TFA Mission is to work with users to develop, implement, and deliver technical solutions through an integrated approach to safely and efficiently accomplish tank waste remediation at five major DOE tank sites.

\section{The Tanks Focus Area}

- brings together the sites' users, technical experts, and efficient management concepts to execute the mission;

- integrates efforts across the sites and utilizes multiple funding organizations; and

- builds teams of users and providers to deliver and deploy technical solutions.

To accomplish this mission, TFA Goals include working to increase OST's funded results, reduce programmatic and technical risk, and pursue contingency or alternative technology approaches.
Pursuant to the mission and these goals, TFA seeks to

- integrate technical solutions into cleanup efforts;

- create plans to address EM's toughest problems, help sites reduce technical risk, and meet compliance agreements;

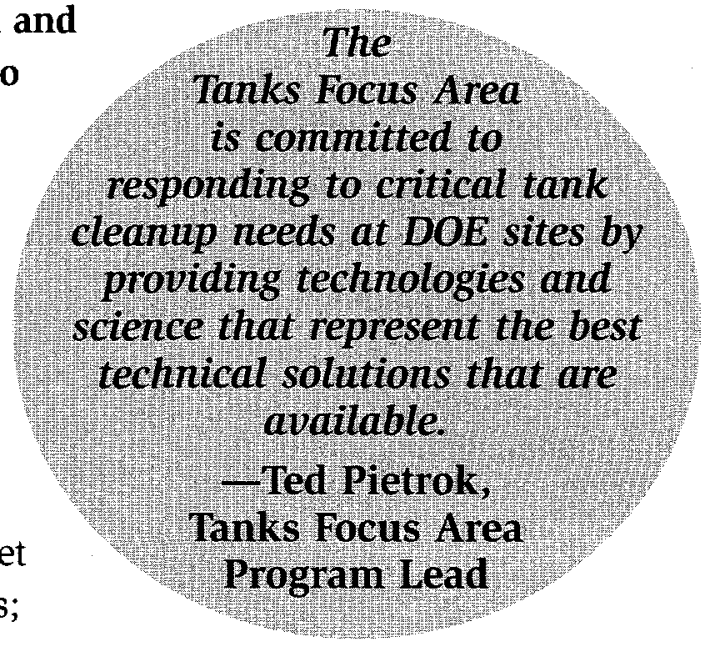

- develop technologies for deployment at multiple sites as the new baseline approach to cleanup;

- reduce environmental risk through comprehensive technical solutions;

- provide services and technologies that enhance worker safety;

- reduce cost and accelerate cleanup schedules;

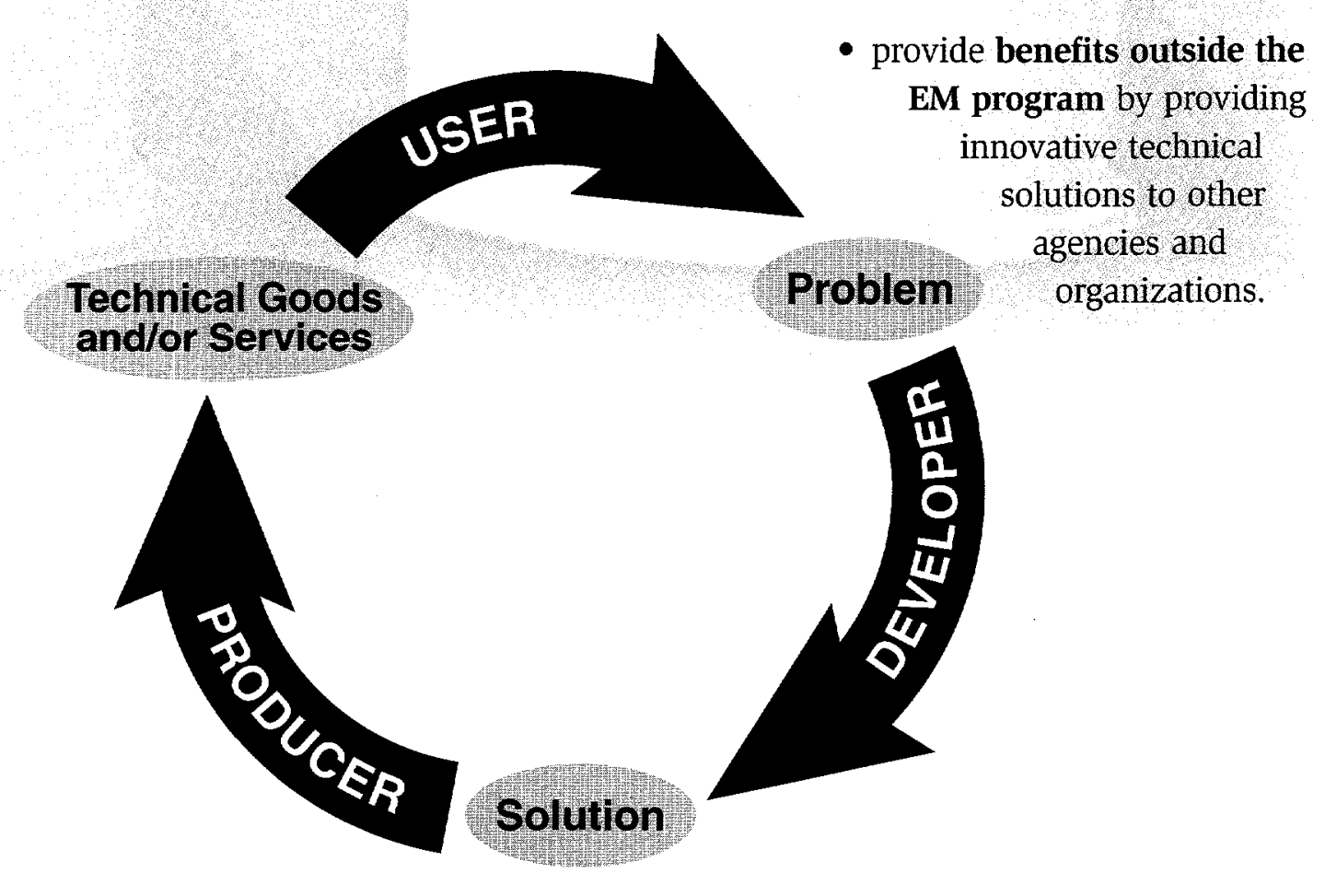




\section{Technical Solutions Are Categorized into Key Process Steps}

Tank remediation follows five key process steps described below. Characterization and monitoring are critical and integral throughout each process step.

Safe Waste Storage-TFA supports site efforts to resolve technical issues associated with safe waste storage. Each site requires improvements in monitoring tank integrity, preventing tank corrosion, ventilating tanks, and characterizing tank waste. Waste minimization technologies are also being implemented to reduce the volume of waste being added to the tanks. TFA is investing in tools to more effectively monitor the conditions of the tanks and more costeffectively maintain safe tank conditions.

Retrieval-Before closure, most radioactive waste tanks require waste retrieval, which must be accomplished with minimal impact on other tank cleanup activities and downstream waste processing. Waste types include solid, sludge, liquid, gas, and miscellaneous debris, each type and combination presenting unique challenges. Retrieval requires remotely controlled equipment operations with tools able to enter underground tanks through small openings. Retrieval processes must also avoid causing waste to congeal or solidify, resulting in plugged transfer pipes. Characterizing and monitoring waste chemistry and physical properties help avoid unwanted solids formation during retrieval and transfer. TFA is developing methods that mobilize hard, solid waste at tank bottoms ("heels") without adding water, while still enabling optimal transfer and treatment properties.

Closure-Closure of tanks is important for reducing costs and accelerating cleanup while minimizing the potential for release of wastes to the environment. The current baseline practice for closing tanks is to fill them with a grout formulation to immobilize tank waste residues. Technical solutions are being used to stabilize residual waste and provide structural integrity and isolation for emptied tanks. TFA is developing characterization solutions to support the negotiation of closure criteria within regulatory constraints and tank cleaning methods that do not introduce excess water or chemicals with undesirable effects on downstream processes. TFA is also considering long-term stewardship issues within its technical solutions for closure. Closure solutions also address the final disposition of immobilized waste forms retrieved from tanks.

\section{Pretreatment-Once} retrieved, waste must be immobilized into a stable waste form. However, directly immobilizing all retrieved waste without pretreatment steps would be unnecessarily expensive and exceed planned storage space. Radionuclide separations are critical to isolation of low- and highactivity fractions. Therefore, TFA is developing waste minimization solutions to separate waste types and reduce high-level waste (HLW) volumes. In addition, process monitoring technologies are
Closu

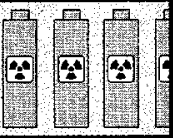

High-Level Waste
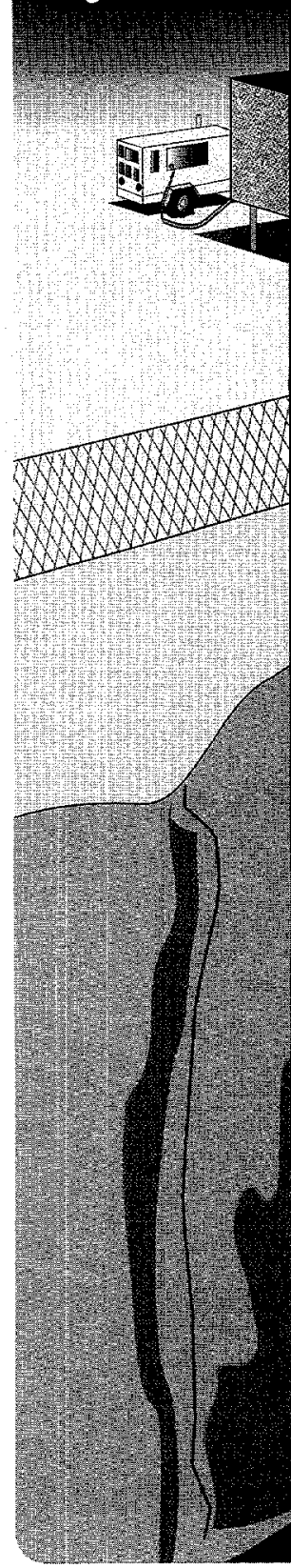
needed to improve operations of pretreatment systems.

Immobilization-Sites must immobilize their waste into solid and stable forms that prevent release of radioactivity or hazardous chemicals to the environment. The highly radioactive waste is melted into a durable, vitrified (glasslike) form. The less hazardous fraction of radioactive waste is immobilized through vitrification or grouting. TFA continues to provide technical solutions to DOE to enhance glass and grout formulations and improve melter and waste product performance. Process and performance monitoring methods are also being evaluated to improve immobilization operations.

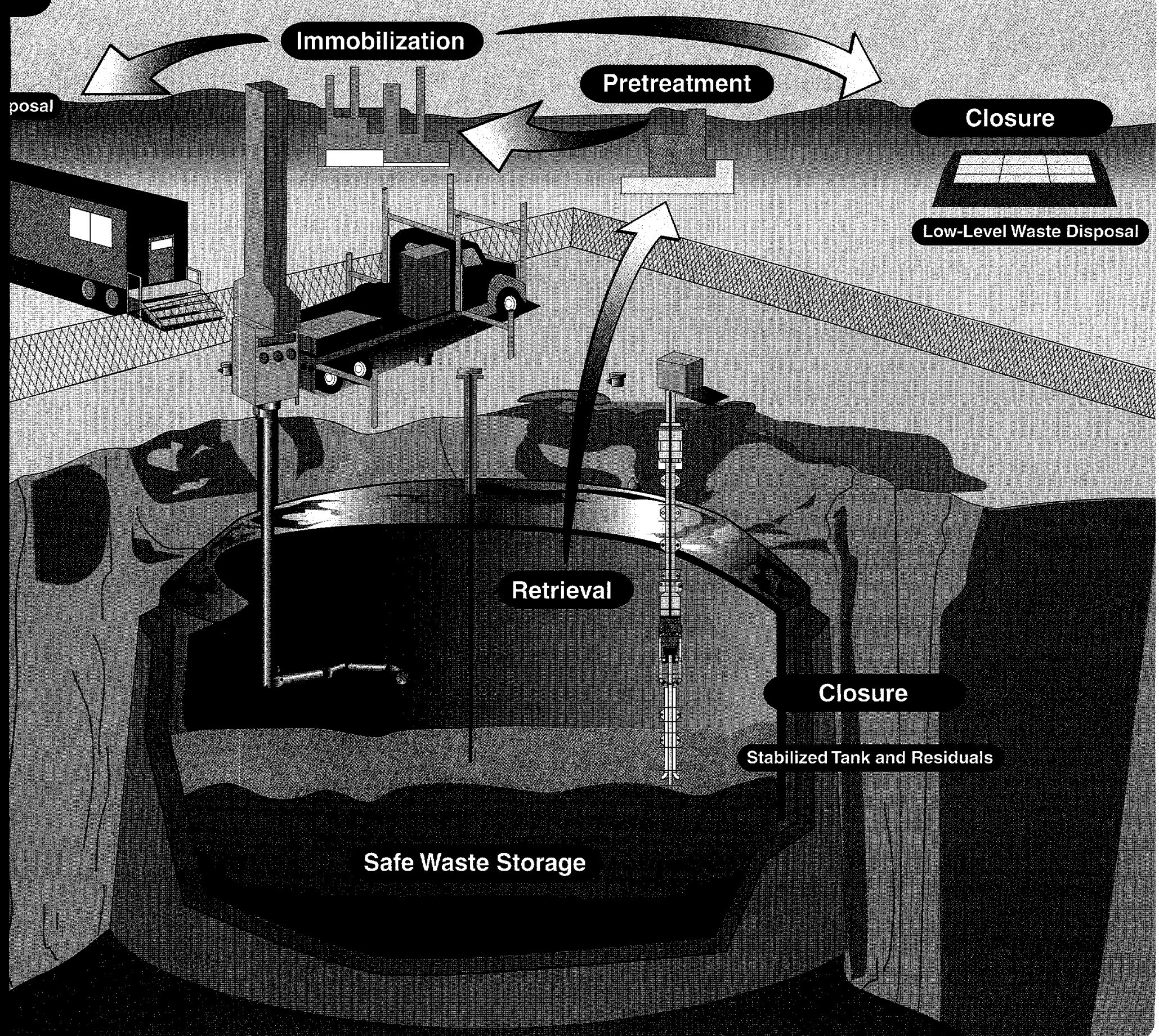




\section{TFA's Success Is Aided by Three Key Program MANAGEMENT AND IMPLEMENTATION CONCEPTS}

- Needs based

- Leveraged resources

- User driven

Each of the DOE sites provides its science, technology, and long-term stewardship needs to TFA and the other focus areas annually. The needs set identifies the areas in which the users need technical solutions to reduce uncertainty, risk, cost, and schedule in their cleanup programs. Therefore, it is the primary basis for the technology development program. TFA actively works with the sites through its network of Technology Integration Managers (TIMs) to understand the problem to be solved, the required performance specifications, the timing of the technical solution, and its integration with other functions.

Once site needs are clearly understood, TFA - through the TIMs-leverages a vast array of resources to develop technical responses that will solve the problems identified in the need. The technical solutions are derived from resources such as academia, industry, and various DOE programs. In addition, TFA strives to identify solutions that will solve needs at multiple sites and ultimately become part of the baseline approach to cleanup. In these ways, leveraging enables TFA to maximize the technical strength of the program and make the most efficient use of appropriated funding. The leveraging of all available resources is the essence of the focus area-centered approach.

To ensure that the provided needs sets include the most critical priorities at the sites, that the technical solutions will meet the needs, and that TFA addresses both near- and long-term site issues, TFA uses a management team approach. The TFA Management Team, composed of DOE representatives from each site and the appropriate DOE Headquarters offices, prioritizes TFA technical responses annually prior to development of the OST budget request. In addition to the TFA Management Team, TFA utilizes a User Steering Group, which consists of senior-level managers from contractors at tank waste sites and national laboratories who advocate the TFA program. In these ways, the TFA program is assured of being user driven.

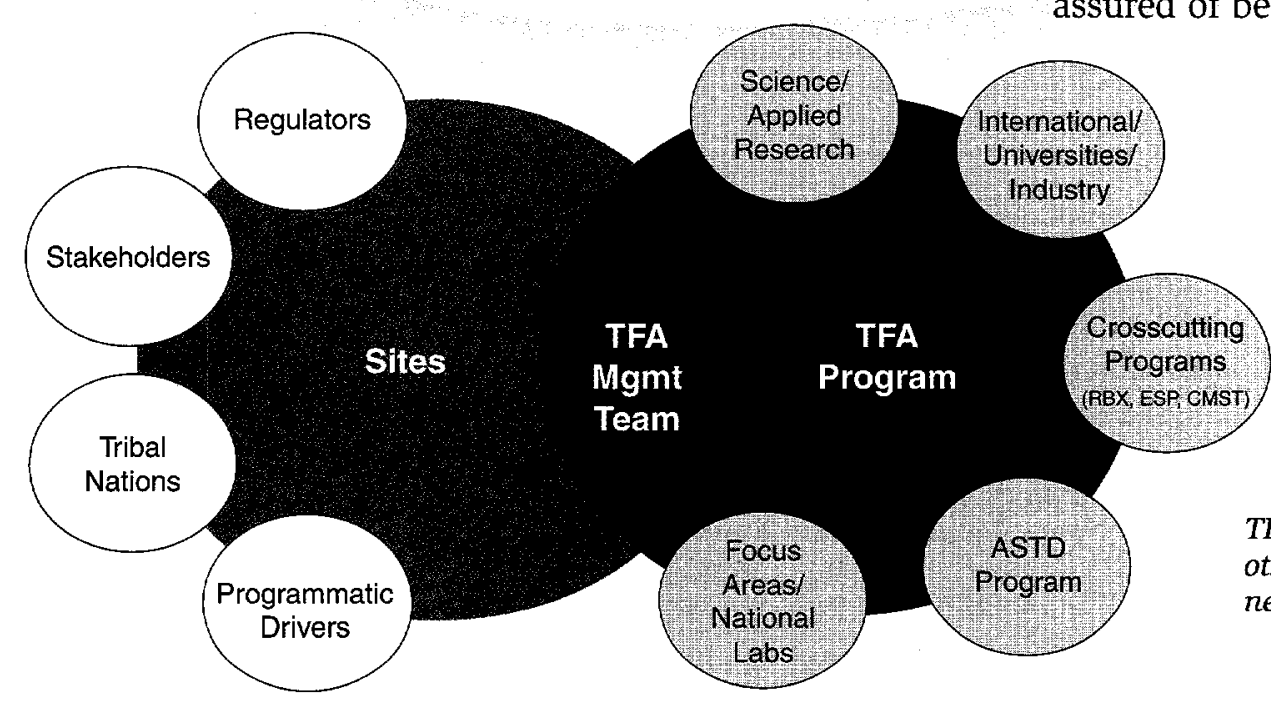

TFA integrates programs and other resources to meet the needs of sites. 


\section{Partnership Programs Support the Focus Area-Centered Approach}

OST's program components are fully integrated into TFA's Focus Area-Centered Approach. Through its integration role, the TFA and its partners strive to ensure planned and ongoing science and technology development work supports the user's needs without duplication.

Crosscutting Programs-The OST focus areas share three common science and technology disciplinary needs:

- Efficient Separations and Processing enables segregation of waste by distinct chemical and physical properties.

- Robotics utilizes remotely operated machines to characterize and handle wastes, preventing unnecessary human and environmental exposure.

- Characterization, Monitoring, and Sensor Technology develops enabling tools for identifying and analyzing waste constituents throughout all aspects of the cleanup process.

Industry Programs-Through DOE's National Energy Technology Laboratory, private-sector companies work cooperatively with TFA in developing technical solutions for deployment at DOE sites.

\section{University Programs-Coordinates} research and development of technologies that foster relations between universities and industry for advancement of science and engineering capabilities.

International Programs-Augments DOE's investments in science and

technology by providing solutions based on waste remediation lessons learned from other nations.

\section{Environmental Management Science} Program (EMSP) - Focuses on scientific research that supports environmental decisions, technical risk reduction, and advanced technologies.

\section{Accelerated Site Technology Deployment (ASTD)-Facilitates the implementation of proven technical solutions across the DOE complex.}

\section{Long-Term Stewardship-Addresses}

issues related to the hazards that will remain after DOE completes cleanup of sites to ensure that selected remedies will remain protective of future generations. 


\section{FISCAL YEAR 2000 TFA ACCOMPLISHMENTS}

- 24 Deployments in radioactive tank waste remediation environments

- 8 Demonstrations to support future deployment decisions

- 5 Ready for Implementation, proven technical solutions that are validated by users at DOE sites and documented in Innovative Technology Summary Reports

The following pages highlight several key technical solutions delivered by TFA during FY 2000. Technologies are identified by their Tech IDs in OST's Technology Management System (TMS). The TMS database provides access to information relevant to EM programs, technical solutions, cleanup problems, and sites. TFA has approximately 100 listings in TMS, viewable at http://tms.em.doe.gov.

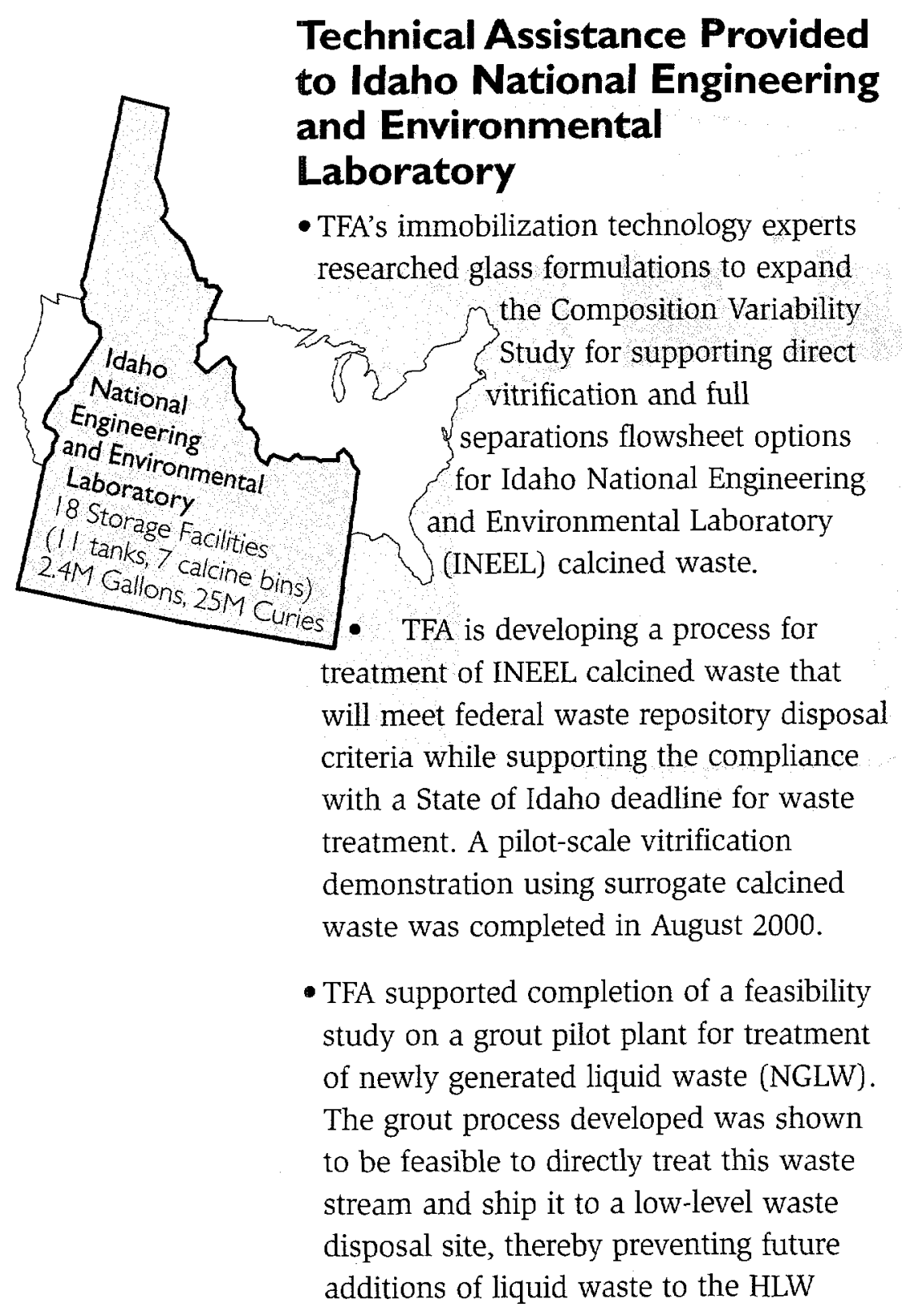

tanks. TFA also supported INEEL in investigating alternatives for treatment of sodium-bearing waste (SBW), including the option to incorporate pretreatment processes into the NGLW grout pilot plant to enable SBW to be treated with the same process.

- At INEEL's request, TFA evaluated the technical feasibility and applicability of a steam-reforming process for treating INEEL's SBW. The TFA report recommended that DOE-Idaho not pursue further steam-reforming initiatives for treating the SBW to produce a waste form for disposal in a federal HLW repository or in the Waste Isolation Pilot Plant. As a result of this investigation, steam reforming may still be considered as an optional treatment process for secondary waste streams generated by the direct vitrification process.

- At the request of DOE-Idaho, TFA conducted an independent assessment of alternatives being considered for treatment of SBW and calcine waste as part of the environmental impact statement process. The TFA review resulted in a recommendation to select direct vitrification as the preferred alternative for treatment of SBW. The review also 
concurred with the site recommendation that a final record of decision on calcine waste treatment be extended to allow time for further investigation of key technical questions. This recommendation supports critical state agreement milestones for treatment and disposal of the liquid SBW. On this basis, DOE-Idaho recommended a baseline change to direct vitrification as the preferred treatment option for both SBW and calcine. Further investigations will support a future decision on the need for pretreatment processes for the calcine waste.

- TFA assembled a second expert panel that reviewed the proposed technology development roadmap supporting direct vitrification of SBW. The review concluded that the proposed roadmap is technically valid, reasonably comprehensive, and feasible, assuming management of programmatic constraints can be achieved.

\section{Integration of Key Environmental Management Science Program Developments into TFA Projects}

TFA Salt Processing Project - Next Generation Crown Ethers (EMSP 55087), New Silicotitanate Waste Forms (EMSP 60345), and Foaming in Radioactive Waste Treatment (EMSP 60143)

TFA is managing the research and development program for the Salt Processing Project at the Savannah River Site. Three candidate cesium removal technologies are being considered for down-selection:

- Crystalline Silicotitanate (CST) Non-Elutable lon Exchange,

- Caustic Side Solvent Extraction (CSSX), and

- Small Tank Tetraphenyborate Precipitation (STTP)

The integration with EMSP is clearly important, considering that two of the three potential processes (CST and CSSX) directly relate to research conducted under EMSP. The principal investigators (PIs) from these EMSP projects are funded through TFA to bring their expertise and creativity to the development and selection process for this critical DOE project. The third

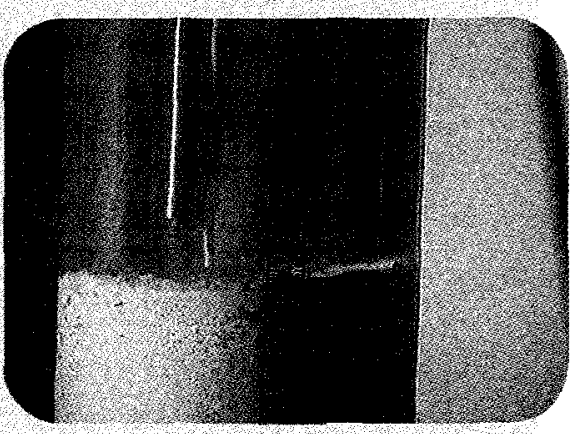

CST fine precipitate. process (STTP) experienced foaming issues, and the EMSP PI investigating foaming was brought in to help evaiuate and select optimal antifoaming agents.

TFA HLW Melter Improvements-Millimeter-Wave Measurements (EMSP 65435) Initial development of the millimeter-wave guide to measure melt properties was so promising that the instrument was demonstrated during TFA-sponsored pilot-scale melter studies at Clemson University.

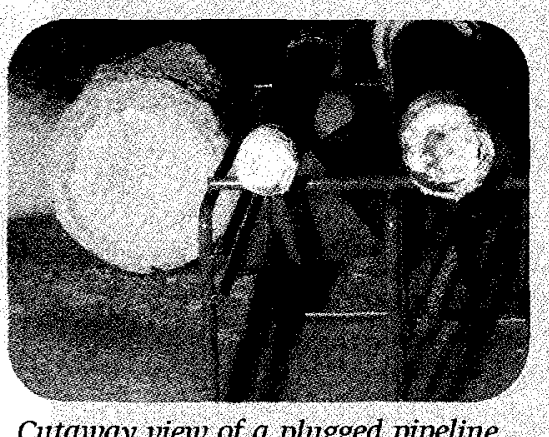

Cutaway view of a plugged pipeline.
TFA Solids Formation Investigations - Predictive Modeling of Phase Separation for Strontium, Americium, and Curium (EMSP 54621) DOE sites use a software model, Environmental Simulation Program (ESP), to predict conditions that could plug pipelines during transfers of radioactive waste. TFA is helping improve the model with additional data for compositions not covered by the current model. The EMSP PI was directly funded by TFA to upgrade the ESP model with energy parameters from EMSP research.

TFA Long-Term Glass Performance - Silica Reactivity in Subsurface Environments (EMSP (55042) and lon-Exchange Processes and Mechanisms in Glasses (EMSP 60362 )

These projects demonstrate another benefit of the two-way interchange between TFA programs and EMSP projects. In the previous cases, EMSP Pls were funded directly by TFA to perform additional tasks related to their EMSP work; in this example, the knowledge developed through EMSP projects modified the TFA program evaluating issues associated with long-term stability of waste glasses. 


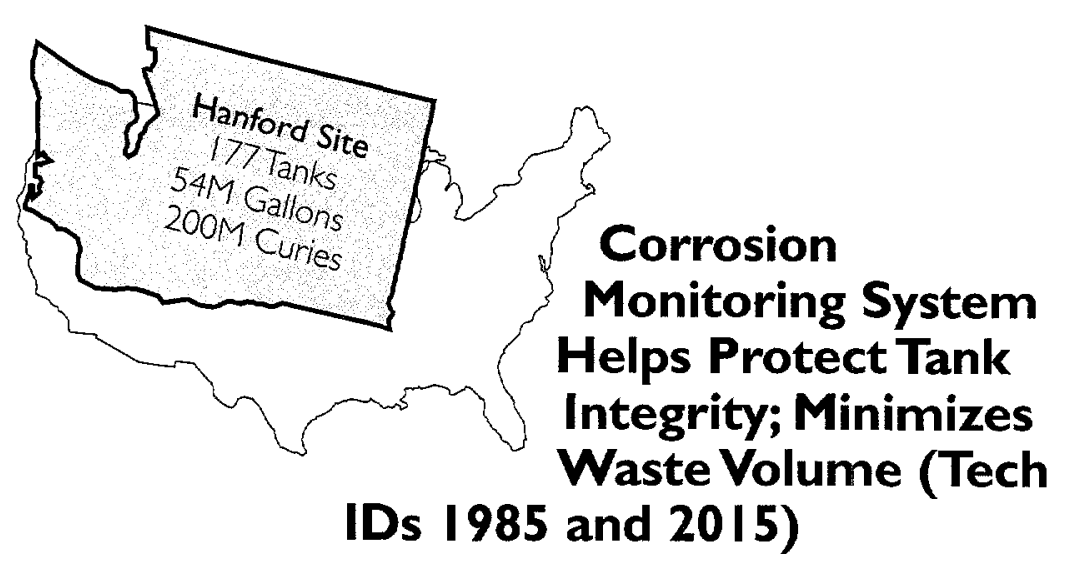

Since many DOE tanks have exceeded their design lives and it will be many years before the waste is retrieved, long-term integrity of storage tanks is critical to maintaining safe storage of radioactive waste. Much of the radioactive liquid waste around the DOE complex is stored in carbon-steel tanks that are susceptible to nitrate ion-induced corrosion cracking. Baseline corrosion control methods involve the addition of a corrosion inhibitor ( $a$ caustic sodium hydroxide solution) to maintain a protective $\mathrm{pH}$ level that inhibits the corrosion process. The sodium adds to waste volumes requiring treatment and disposal. Fine-tuning corrosion inhibitor additions through improved monitoring can

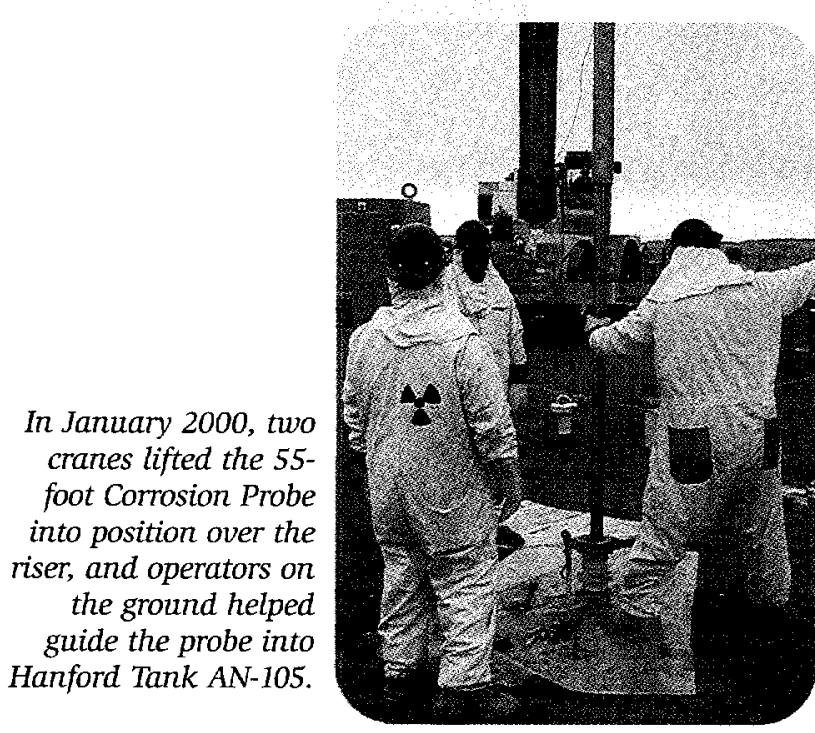
minimize additional waste volumes and associated processing costs.

To combat corrosion of tank walls and improve the corrosion control process, TFA and partners at the Hanford Site have worked together to develop and deploy an electrochemical noise (EN)-monitoring device called the EN Corrosion Monitor
System. The monitor detects electrochemical reactions during the corrosion process and interprets these signals to identify the type (uniform or localized) and extent of corrosion taking place. In January 2000, tank farm operations staff at the Hanford Site completed installation of a Corrosion Probe into double-shell tank AN-105. This was the fourth Corrosion Probe installed at Hanford with TFA support. The probe's integrated data analysis software provides real-time data, enabling operators to take quick and effective actions, while refining and minimizing the amount of corrosion inhibitor added to the waste. While the principles of the EN technology have not changed since installation of the first probe, enhancements to the design and datagathering equipment-particularly the new electrode pass-through and updated software-are expected to provide significant improvements in performance. In addition, multiple features on the upgraded probe enable numerous functions to occur using only a single riser. Because riser demands are high, this capability is critical to making these features available to Hanford Site users when needed.

TFA also funded efforts to develop an Integrated Corrosion Probe Monitoring Station to serve as a central data collection point for the various corrosion probes installed in Hanford's AN Tank Farm. The Integrated Corrosion Probe Monitoring Station was successfully installed in the AN271 instrument building in August 2000. Based on the final probe design, another corrosion monitoring system (EN probe plus aboveground cabinets and instrumentation) is scheduled for installation in FY 2001. This system will also be routed back to the integrated corrosion monitoring station.

A probe under development the Savannah River Site (SRS) both continuously monitors 
corrosion using EN technology and measures concentrations of corrosive waste

constituents and corrosion inhibitors using Raman spectroscopy. SRS plans to combine the Raman Probe capabilities with those of the EN Corrosion Probe to determine the optimum chemical species concentrations for controlling corrosion while minimizing sampling requirements.

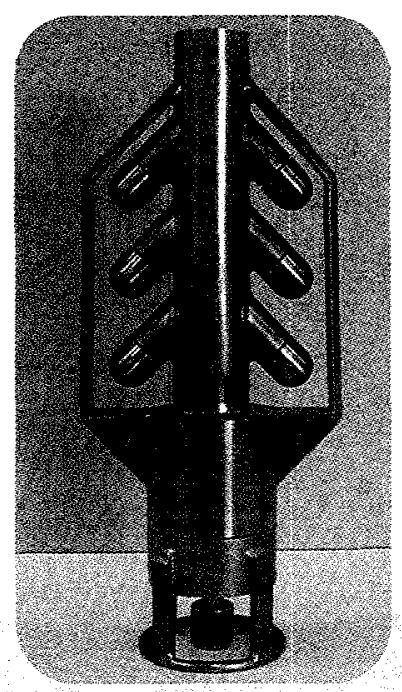

The combined probe includes the Raman portion at the bottom, threaded into the electrochemical noise portion at the top. The six electrodes on this array will provide realtime corrosion data, while the Raman instrument will provide real-time analysis of the chemical species in the waste.

\section{Fluidic Sampler Successfully Demonstrated (Tech ID 2I 19)}

Baseline slurry/supernatant tank waste sampling methods at the Hanford Site employ conventional "grab" sampling techniques, which can capture nonhomogeneous samples, require multiple operations to obtain a sufficient sample volume, and also present exposure risks to workers. A representative-and preferably rapid-sampling and analysis system needs to be developed and demonstrated, to support delivery of waste feed to the waste treatment plant. Tank farm operations personnel must verify the contractually specified bulk constituents and radionuclides before batch transfer of waste.

TFA has funded the development of the variable-depth Fluidic Sampler, which uses a vertical sample hold-up reservoir as an integral part of the existing sample line. In this new design from an international partner, the sample bottle is filled to near-zero headspace without using a vacuum to draw samples. The initial demonstration of the RCRA-compliant fluidic sampling method in January 2000 resulted in some sand surrogates remaining in the sample reservoir. Following a redesign, results from follow-up testing showed that surrogates containing sand completely drained from the sample hold-up reservoir into the sample bottle. The Fluidic Sampler will be safer to operate, require less maintenance, and provide larger and more representative samples than the baseline method.

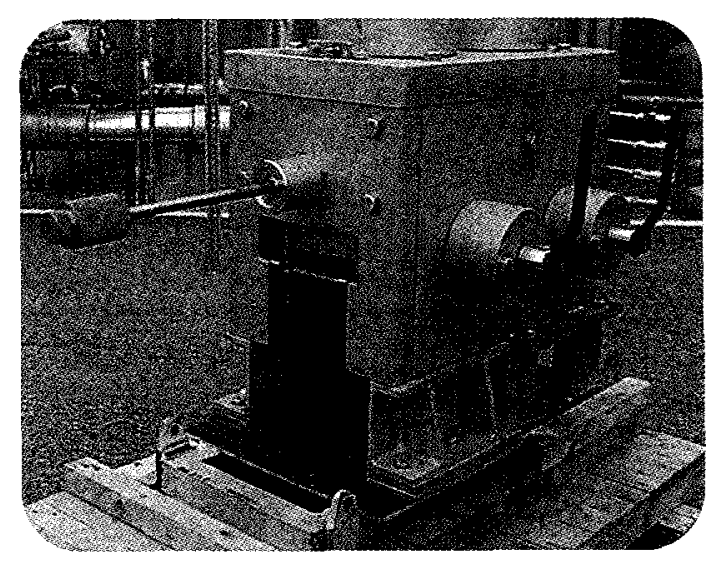

TFA and AEA Technology are adapting the fluidic sampling technology deployed at SRS to develop a mobile, variable-depth sampling system that can be used on multiple-feed staging tanks at the Hanford Site. The top of the Fluidic Sampler, which attaches to the sample bottle, is contained within a sampling station shown above. This feature enables remote sampling, provides better contamination control, and exposes operators to less risk than baseline "grab" sampling methods.

\section{The}

Tanks Focus Area is an active partner in many parts of the River Protection Project. For example, TFA sponsors waste chemistry analysis and modeling, which is a key component of our system design efforts and project planning. Many TFA/OST sponsored activities have been used in the waste treatment plant design. Additionally, the Office of River Protection recently negotiated an aggressive new schedule for the Tri-Party Agreement (Federal Facility Consent Agreement) with the Washington State Department of Ecology. The new schedule includes commitments to deploy new and improved retrieval and leak detection technology for our single-shell tanks. We are looking forward to continuing our successful partnership with the TFA. ,

E. J. Cruz, TFA Management Team Site Representative, Office of River Protection 

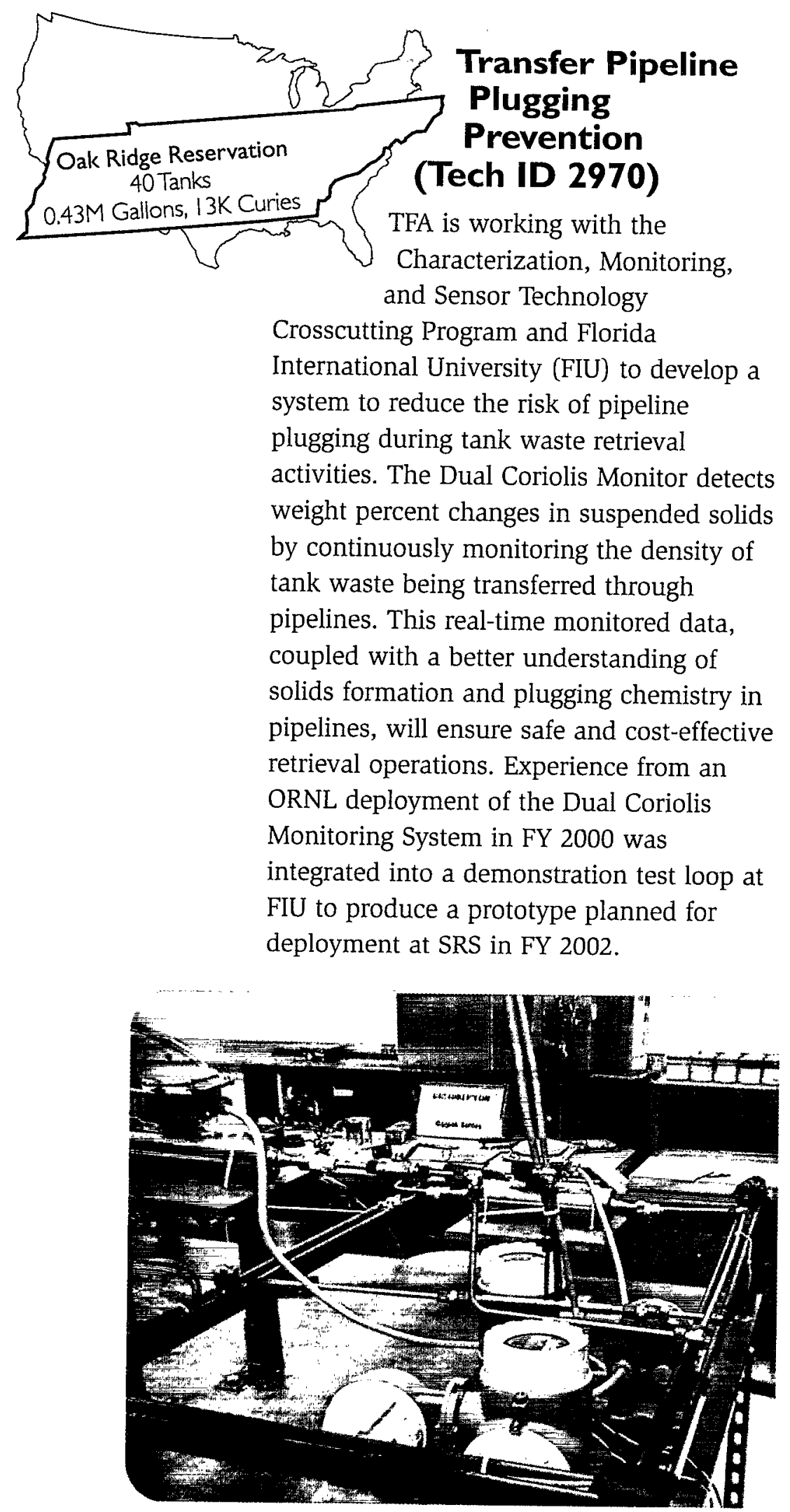

Dual Coriolis density meters in the FIU test loop.

\section{Pipeline Unplugging Methods under Development (Tech ID 2367)}

TFA is also working with Industry

Programs to sponsor a demonstration of - pipeline unplugging methods at FIU using specially constructed testbeds. Several effective means of removing simulated blockages in pipelines were demonstrated. One uses sonic resonance to apply varying vibration frequencies, breaking the bond holding the blockage to the pipe. Another method uses water pressure and scouring inserts called "pigs" to remove blockages.

\section{Gunite Tank Waste Retrieval Completed (Tech IDs 85, 8 I 2, 2085, 2 I I 6, 2 I 94, I 5 I 0, 2093, 2232, and 2384)}

In the 1990s, sluicing operations at the Oak Ridge Reservation (ORR) removed the bulk of the waste in the site's Gunite and Associated Tanks (GAATs). However, residual sludge remained at the bottom of the tanks, hindering closure activities. TFA and its partners, including the Robotics Crosscutting Program, have worked with users at ORR to develop a suite of technologies to help the site fill technology gaps and meet compliance schedules for tank waste retrieval while reducing personnel exposure.

For example, beginning with GAAT W-3 in 1998, the Modified Light Duty Utility Arm (MLDUA), Houdini vehicle, and Confined Sluicing End Effector retrieved and consolidated sludge waste from the gunite tanks into GAAT W-9. There, the waste was conditioned to enable safe transfer of sludge/slurry to the Melton Valley Storage Tanks (MVSTs) to await treatment, leaving a dense sludge layer at the bottom of W-9. 
During August and September 2000, Oak Ridge National Laboratory (ORNL) staff used the Heavy Waste Retrieval System in conjunction with the MLDUA and Houdini vehicle to complete retrieval and transfer of sludge and slurry waste from W-9 to Bethel Valley Evaporator Service Tank W-23. At W23 , the waste was mixed to allow the heavier particles to settle out; then the slurry was transferred to the MVSTs to await treatment and disposal. More than 156,000 gallons of waste was transferred during the final cleanout of W-9. The Tennessee Department of Oversight, Environment and Conservation inspected the tank in September and concurred that it was sufficiently clean to cease wasteremoval operations.

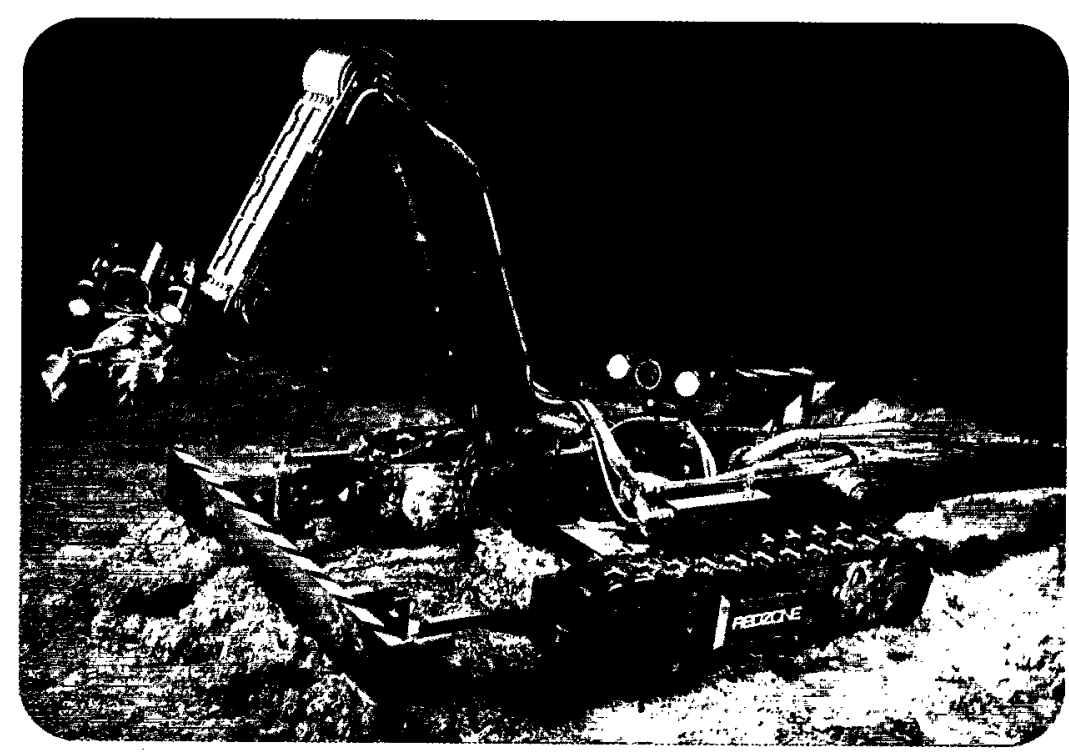

By integrating the Confined Sluicing End Effector with the remote capabilities of the Modified Light Duty Utility Arm and the Houdini vehicle (pictured here), TFA helped deliver a highly successful method for retrieving waste from the gunite tanks.

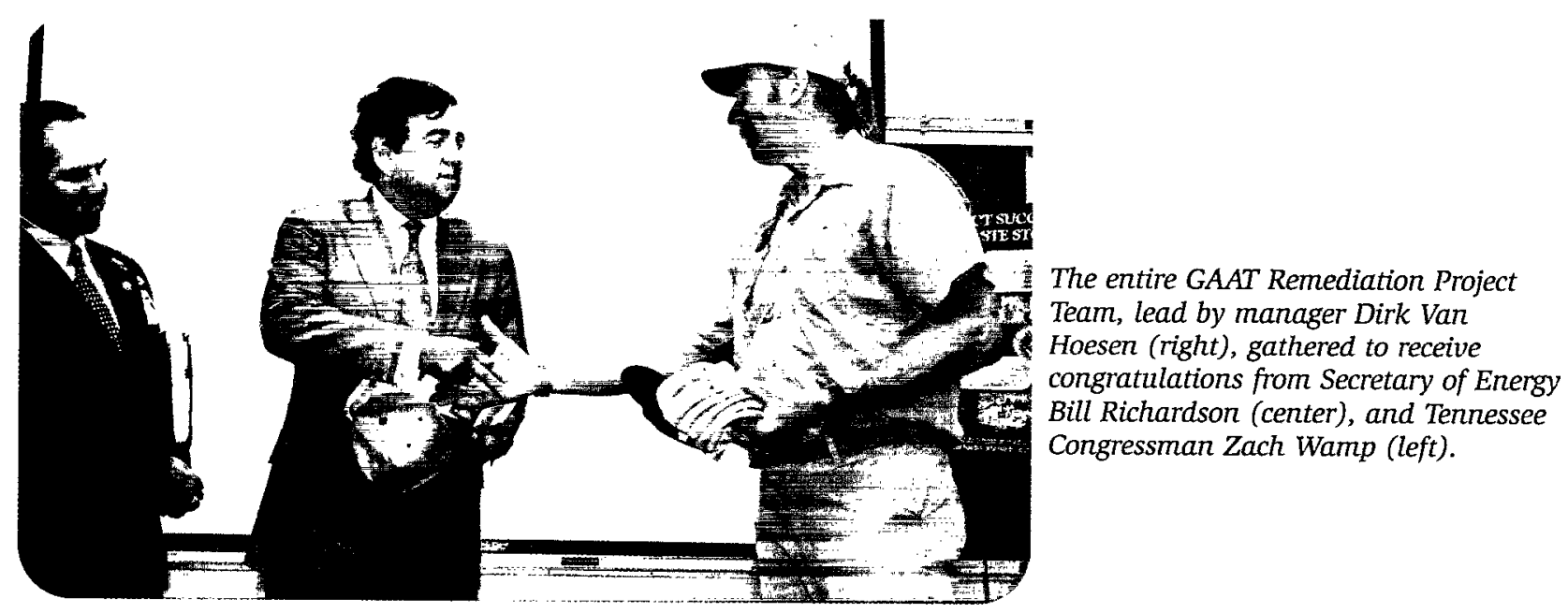

Completion of the gunite tank retrieval operations represents a significant site milestone in cleanup of the GAATs. Results of retrieval activities conducted there provide valuable lessons learned and information for other DOE tank sites to use in evaluating retrieval options and developing plans for future retrieval projects.

\section{"The}

contributions of the

Tank Focus Area are

immeasurable to the Environmental

Management Program at Oak Ridge.... Removal of this material from the [gunite] tanks prevented potential risk to workers, the public, and the environment. This project was the first of its kind completed in the United States...Many of these technologies were funded through TFA. We were able to complete the GAAT project 12 years ahead of schedule."

Daryl Green, TFA Management Team

Site Representative, Oak Ridge Operations Office 


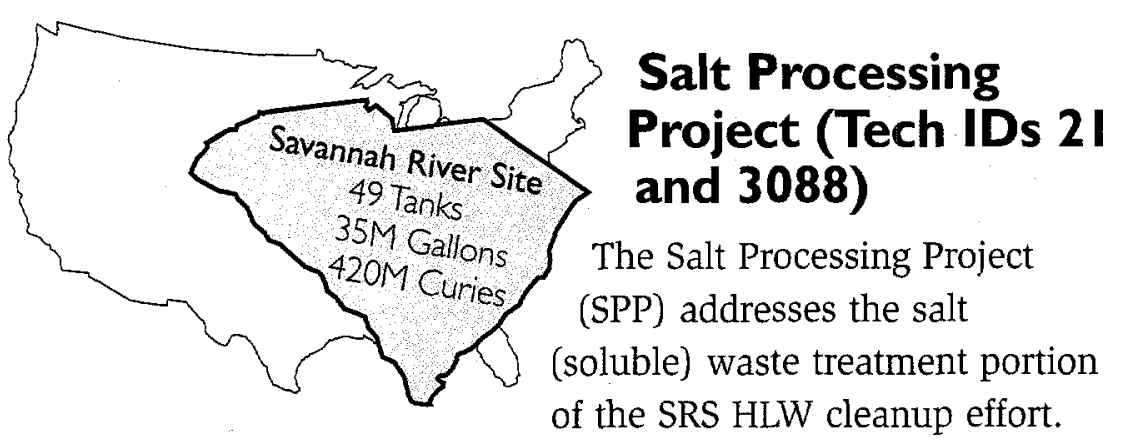

This critical project encompasses the selection, design, construction, and operation of pretreatment technologies and facilities to prepare salt waste feed material for subsequent treatment at the site's Saltstone Facility and Defense Waste Processing Facility (DWPF). In March 2000, DOE asked TFA to manage the research and development portion of the project and specifically to review and revise the existing technology development roadmaps, develop selection criteria, and prepare a comprehensive $R \& D$ program plan for three candidate cesium removal technologies, as well as the alpha and strontium removal technologies that are part of the overall SPP.

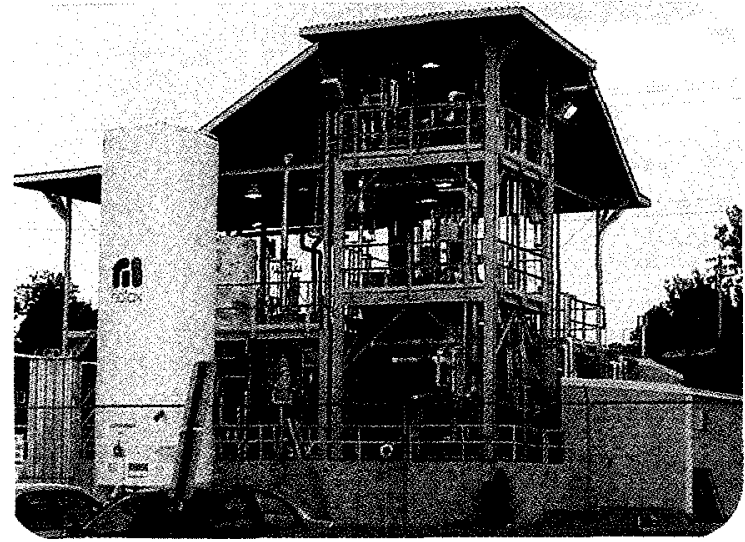

The University of South Carolina's Filtration Research Engineering Demonstration facility was used to demonstrate crossflow filtration in the alpha and strontium removal process.
- The Alpha and Strontium Removal process step removes the soluble uranium, plutonium, and strontium contained in the salt solution. In the cases of cesium removal (e.g. Small Tank Tetraphenylborate Precipitation), alpha and strontium removal occurs simultaneously with precipitation of cesium. In the CST Nonelutable Ion Exchange and Caustic Side Solvent Extraction cesium removal processes, alpha and strontium removal must occur before removing cesium from the solution, increasing process complexity and necessitating a solid-liquid separation step.
The three candidate cesium removal technologies are as follows:

- cST Nonelutable Ion ExchangeThis process uses three ionexchange columns in series to adsorb cesium onto CST. The decontaminated salt solution is then combined with evaporator

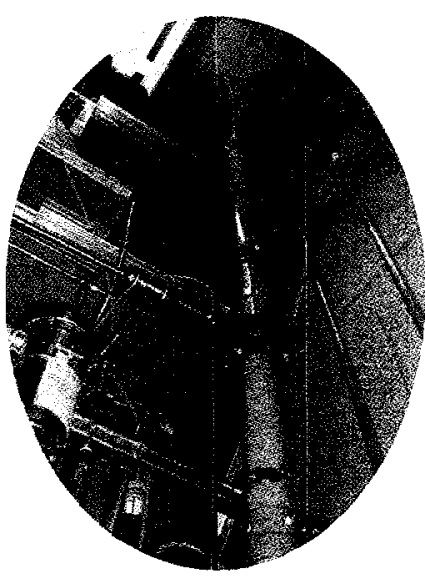

Ion-exchange column loaded with crystalline silicotitanate. concentrate from the Effluent Treatment Facility, followed by solidification and disposal as saltstone grout. The cesiumloaded CST is transferred as a slurry to the DWPF for incorporation into glass.

- Caustic Side Solvent Extraction-In this process, a sparingly soluble diluent material carries an extractant that complexes with cesium ions in the caustic solution. This process results in two waste streams: a decontaminated waste stream disposed of as saltstone grout and another including the cesium, which is sent to DWPF.

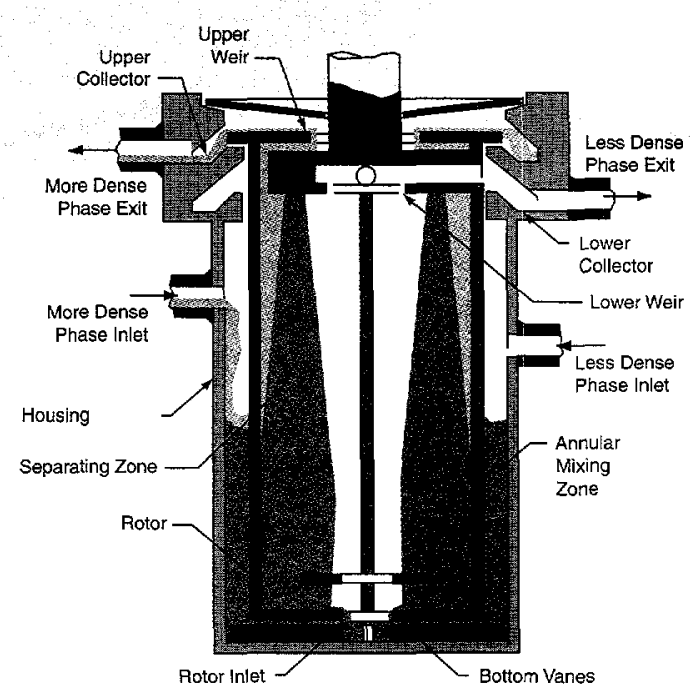

Caustic side solvent extraction occurs in a series of centrifugal contactors, one of which is shown here in cutaway view. 
The SPP Research and Development Program is funded jointly by the DOE Offices of Science and Technology (EM50) and Project Completion (EM-40). Participants in the program include the Savannah River Technology Center, Oak Ridge National Laboratory, Argonne National Laboratory, Sandia National Laboratories, Pacific Northwest National Laboratory, and various universities and commercial vendors.

\section{-Small Tank Tetraphenylborate}

Precipitation-This process uses chemical precipitation/adsorption and filtration to separate cesium-137, strontium-90, and plutonium from salt solutions into a low- volume, high-radioactivity waste stream (the "precipitate") and a high-volume, lowradioactivity waste stream (the "filtrate"). The precipitate is washed to reduce the nitrite concentration prior to transfer to DWPF for incorporation into glass; the filtrate is combined with evaporator concentrate and then solidified and disposed of as saltstone grout.

The R\&D program is responsible for resolving high-risk issues and delivering technical results on the alpha/strontium removal process and each cesium removal process to support $\mathrm{DOE}$ selection of a preferred salt waste pretreatment option and initiation of associated design activities.

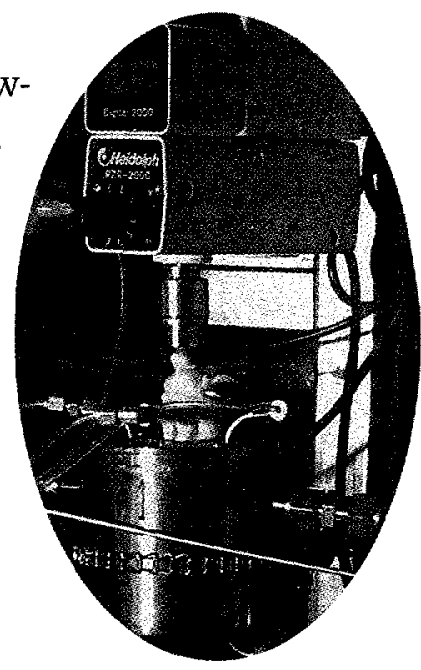

Small Tank Tetraphenylborate Precipitation process equipment is tested in a hot cell with actual waste samples.

\section{Progress in FY 2000}

\section{Alpha and Strontium Removal \\ Sorption Kinetics}

- Verified design bases through sorption studies on monosodium titanate

- Identified alternative testing materials

$\checkmark$ Initiated characterization of soluble actinides in real waste

\section{Solid Liquid Separation Studies}

- Demonstrated flux rates at or exceeding designing requirements through large-scale filtration tests with simulated sludge and monosodium titanate

- Initiated tests on candidate chemical additives

r Completed survey of alternative solid-liquid separation technologies

\section{CST Nonelutable lon Exchange Sorbent Stability}

- Verified cesium toading in column test using real waste - Observed column plugging in real waste and simulant tests - Initiated contract for manufacturing modifications to reduce leaching of excess materials

- Validated Texas A\&M equilbrium model for cesium loading at various temperatures

\section{Gas Generation}

-Conducted small-column tests in High Flux Isotope Reactor fuel element that showed no adverse effect of radiolytic gas generation on cesium sorption

- Measured thermal conductivity data to support models - Prepared tall-column system for gas disengagement tests Sorbent Handling and Sampling

- Conducted sampling tests with Hydragard ${ }^{\mathrm{m}}$ Samplerperformance was unchanged by presence of CST - Demonstrated CST size reduction in two vendor tests - Demonstrated the ability to effectively mix size-reduced CST, including resuspension after six days of settling

\section{Caustic Side Solvent Extraction}

Solvent Properties and Stability

- Finalized selection of solvent components and identified potential commercial suppliers

- Completed cobalt-60 external irradiation tests

$\checkmark$ Verified sustained performance of solvent in thermal (chemical) stability tests

\section{Flowsheet Tests}

- Conducted proof-of-concept waste simulant flowsheet tests without solvent recycle, using 2-cm centrifugal contactors

- Met or exceeded target cesium decontamination and concentration factors in flowsheet testing.

\section{Small Tank Tetraphenylborate Precipitation Catalytic Product Decomposition}

- Gained improved understanding of tetraphenyborate decomposition through extensive catalyst experiments

- Demonstrated success of precipitation process in the presence of a significant decomposition reaction using a 20-liter Continuous Stirred Tank Reactor (CSTR)

\section{Reactor/Vessel Foaming}

- Studied the cause of foaming in 10\% potassium tetraphenylborate slurry

- Selected Illinois Institute of Technology's antifoaming/defoaming agent out of three candidates evaluated

- Demonstrated effectiveness of selected antifoaming agent in the 20-liter CSTR

For more information on the SRS Salt Processing Project, see http:I/www.srs.gov/general/sitech/spplindex html 


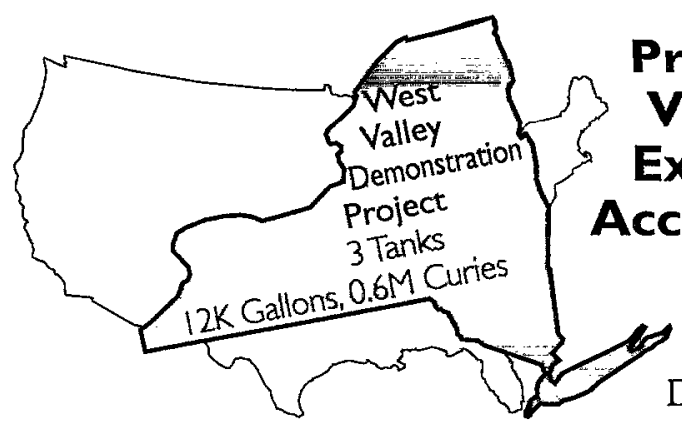

Processing of Vitrification Expended Material Accelerated (Tech ID 2383)

(WVDP), HLW from large

underground storage tanks has been removed and vitrified, generating radioactive waste material in the form of used equipment and instruments, referred to as "vitrification-expended material." This contaminated waste, along with the future wastes from ongoing vitrification operations, will require processing to costeffectively meet disposal facility requirements.

In an ASTD effort, TFA has funded the Vitrification Expended Material Processing System to sort, segregate, size-reduce, chemically and radiologically decontaminate, and package all materials and equipment that have been declared waste. To minimize radiation exposure to workers, waste processing operations are carried out remotely in the vitrification cell and the chemical process cell. The process of preparing HLW-contaminated equipment and instruments into a disposable form

$$
\text { requires various }
$$

$$
\text { "TFA tools, }
$$

is really delivering on

its mission statement by bringing together the problem owners and problem solvers. For example, TFA's role in evaluating the technology alternatives for laying out our path forward for INEEL's calcine

HLW and sodium-bearing waste and in managing the $R \& D$ of the alternative for fission products and actinide separation of SRS's salt

HLW has been invaluable in moving EM's cleanup goals to reality."-Mark Frei, Deputy Assistant Secretary for Project Completion

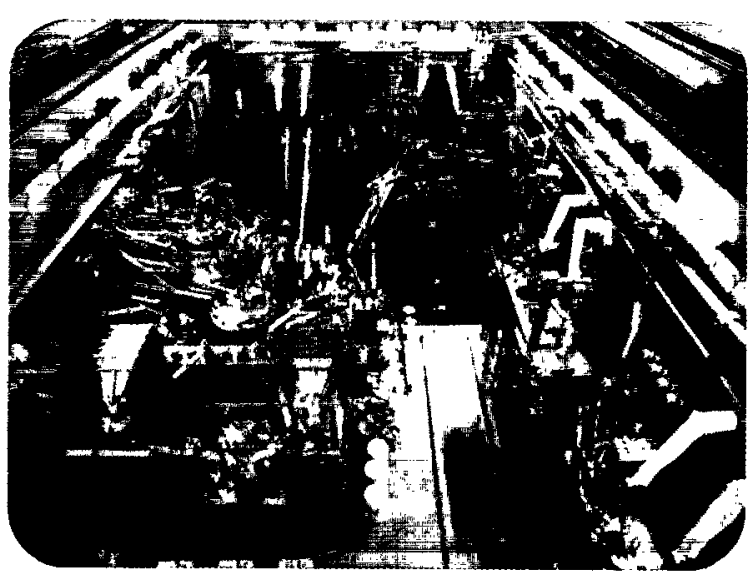

The vitrification cell at West Valley is a reinforcedconcrete, shielded, canyon-type structure that houses all of the major radioactive vitrification process equipment and acts as a confinement barrier.

many of which are modified from commercially available products like cranes, power manipulators, transfer cart and trailer, and remote and shielded viewing equipment. Other tools are custom-designed to fit the unique configuration in the vitrification facility at WVDP. These include a conceptual mobile cutting workstation, remotely operated cutting tools, a water/steam washing system, radiological surveying capabilities, and remote handling equipment and fixtures.

By August 2000, approximately 280 cubic feet of nonstandard HLW had been reduced to 20 cubic feet of HLW and 60 cubic feet of low-level waste. The HLW is awaiting encapsulation in canisters, pending approval by the Office of Civilian Radioactive Waste Management. Accelerated deployment of expended materials processing cuts costs by reducing the volume of waste requiring management and storage following vitrification. In addition to serving as a processing system for HLW-contaminated equipment, the processing system may be used for similar waste already in storage and other highactivity wastes being generated as part of WVDP operations. Subsequent deployments are possible at sites that process HLW, including Hanford, SRS, and INEEL. 


\section{Peer Reviews of TFA Project Progress}

The TFA program review process follows the OST guidelines that establish a uniform and independent process to assess the scientific and engineering merit of technology development activities. In FY 2000, the American Society of Mechanical Engineers (ASME) reviewed three programs that resulted in confirming the technology development approach for each:

\section{- An Alternative Filter Technology is} required to increase the life of HLW tank highefficiency particulate air (HEPA) filters, to reduce the risks of worker exposure during replacement, and to reduce the solid waste volume associated with spent filters. In partnership with the National Energy Technology Laboratory, TFA is funding the development of HEPA filters constructed of sintered stainless steel and ceramic. This HEPA filter technology is not subject to water damage and can be installed with built-in water jets, which will be used to wash the filter to reduce radiation and to eliminate contaminate accumulation. The ASME review conducted in FY 2000 recommended continuing development of both filter technologies. TFA will proceed with full-scale development of both filter technologies leading to selection of one for installation in SRS Tank 11 .

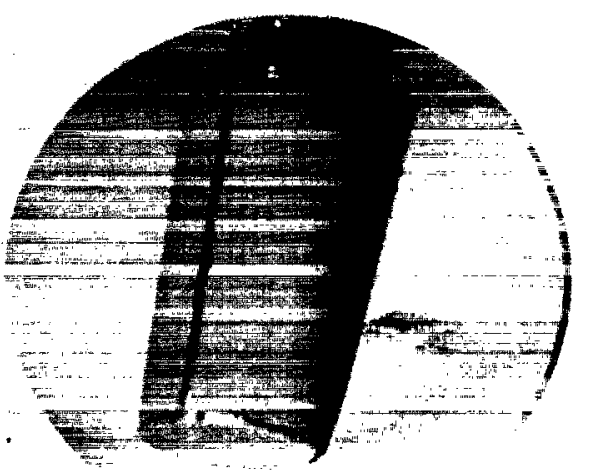

- The High-Activity Waste Forms Program at INEEL is developing vitrification processes capable of immobilizing the site's calcine- and sodiumbearing waste into a qualified waste form ready for disposal by the year 2035. The ASME review provided positive input on the technical approach and management team. On the basis of the review results, TFA management will recommend the task team proceed with planned technology activities in FY 2001.

- The Low-Activity Waste Program at INEEL is investigating the grouting process for immobilizing NGLW produced in the Idaho Nuclear Technology and Engineering Center tank farm. Currently, all liquid wastes are evaporated and the residue is added to the tank farm. The State of Idaho has deemed INEEL's tank farms to be noncompliant with regulatory requirements, and a cease use order must be met by the year 2012 . The ASME review concluded that the technical principles and programmatic approach for grouting the NGLW were sound. Recommendations were made for further review of conformance to ASME/American National Standards Institute standards as well as for greater initial stakeholder involvement: TFA and site partners are proceeding with the grout development program with due consideration of the ASME recommendations

Another peer review group that TFA relies upon is the National Acadeny of Sciences/National Research Council. Its FY 2000 review of TFA sites' long-range science plan recommended that TFA and EMSP solicit proposals in four areas:

- Long-term issues related to tank closure and characterization of surrounding areas

- High-efficiency, high-throughput separations methods that would reduce HLW program costs over the next few decades.

- Robust, high-loading immobilization methods and materials that could provide enhancements or alternatives to current immobilization strategies

- Innovative methods to achieve real-time and, when practical, in situ characterization data for HLW and process streams that could be used for all phases of the waste management program.

Scientists at Savannah River Technology Center are evaluating CeraMem's ceramic filter media (top) and Mott's sintered stainless steel filter (bottom). 


\section{Innovative}

Technology Summary

Reports present the full

range of problems that a technology, system, or process will address and its advantages to the DOE cleanup in terms of system performance, cost, and cleanup effectiveness. - Jef

Walker, DOE Office of Science and Technology

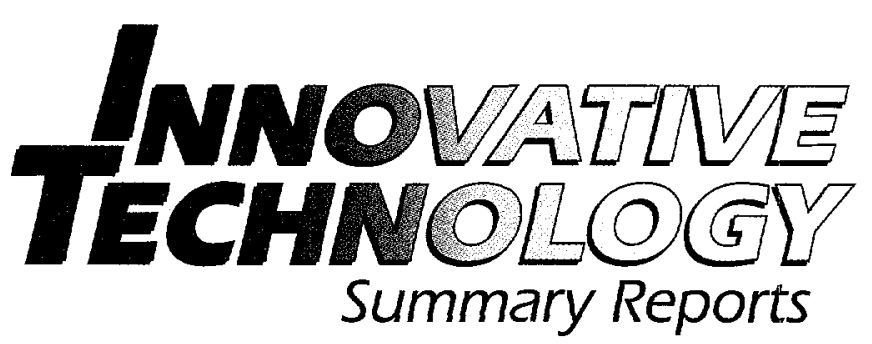

TFA published five new Innovative Technology Summary Reports (ITSRs) in FY 2000, signaling the technologies' "Ready-forImplementation" status to DOE users and others working in the environmental industry. As listed below, a total of 25 ITSRs now describe how risks and costs are being reduced through TFA technology implementation. Published ITSRs are available on the OST Web site at http://ost.em.doe.gov under "Publications."

\begin{tabular}{|l|l|}
\hline Download (Tech ID) & To learn about \\
\hline Safe Waste Storage & \\
\hline Corrosion Probe (1985) & Controlling corrosion, maintaining tank integrity \\
Fluidic Sampler (2007) & Pressurized, stationary sampler for process tanks \\
Laser Ablation/Mass Spectroscopy (127) & Chemical analysis method for tank waste \\
Near-Infrared Spectroscopy (86) & Charting the inside of waste storage tanks \\
Robotic Tank Inspection End Effector (278) NEW & Visual and electromagnetic nondestructive evaluation \\
Stereo Viewing System (890) NEW & Stereoscopic view of tank interiors \\
Topographical Mapping System (130) & Measuring moisture in waste samples \\
\hline Retrieval & \\
AEA Fluidic Pulse Jet Mixer (1511) & Low-maintenance equipment for mobilizing settled solids \\
Borehole Miner (1499) & High-pressure sluicing nozzle to mobilize tank waste \\
Comparative Testing of Slurry Monitors (1547) & Real-time measurement of slurry density \\
Confined Sluicing End Effector (812) & Dislodging waste using high-pressure, rotating water jets \\
Light Duty Utility Arm (85) & Mobile, multiaxis robotic arm for in tank applications \\
Pulsed-Air Mixer (1510) & Using air bubbles to mix tank contents \\
Pretreatment & Cesium removal using high-capacity sorbent to reduce waste volume \\
\hline Cesium Removal Using Crystalline Silicotitanate (21) & Solid/liquid separation methods \\
Crossflow Filtration(350) & Modular evaporator to reduce waste volume and free tank space \\
Out-of-Tank Evaporator (20) & Caustic leaching of nonradioactive chemicals \\
Sludge Washing (233) NEW & Radionuclide removal from high-level waste \\
TRUEX/SREX (347) & Membranes for removing sodium from waste \\
Caustic Recycle (885) & \\
Immobilization & Glass formulations for ion-exchange sorbents \\
Vitrification of Ion Exchange Materials (81) & \\
Closure & Sampling tank waste heels \\
Heel Sampling End Effector (2386) NEW & Analysis of organic and inorganic chemical species \\
Raman Probe (1544) & In-tank cutting, cleaning, and plugging of pipes \\
Pipe Cutting and Isolation System (2093) & Technologies for closing tanks \\
SRS Tank Closure (22) & Sensory system which measures subsurface contaminants \\
Vadose Zone Characterization System (2118) NEW & \\
\hline
\end{tabular}




\section{Portfolio Distribution of Technical Solutions by Maturity Stage}

\begin{tabular}{|c|c|c|c|c|c|c|}
\hline $\begin{array}{c}\text { Basic } \\
\text { Research }\end{array}$ & $\begin{array}{c}\text { Applied } \\
\text { Research }\end{array}$ & $\begin{array}{c}\text { Exploratory } \\
\text { Development }\end{array}$ & $\begin{array}{c}\text { Advanced } \\
\text { Development }\end{array}$ & $\begin{array}{c}\text { Engineering } \\
\text { Development }\end{array}$ & Demonstration & Implementation \\
\hline 49 & & & & & \\
\end{tabular}

\section{Distribution of TFA FY 2000 Program Budget}

(\$47.9M total budget including \$10.IM EMSP investment)
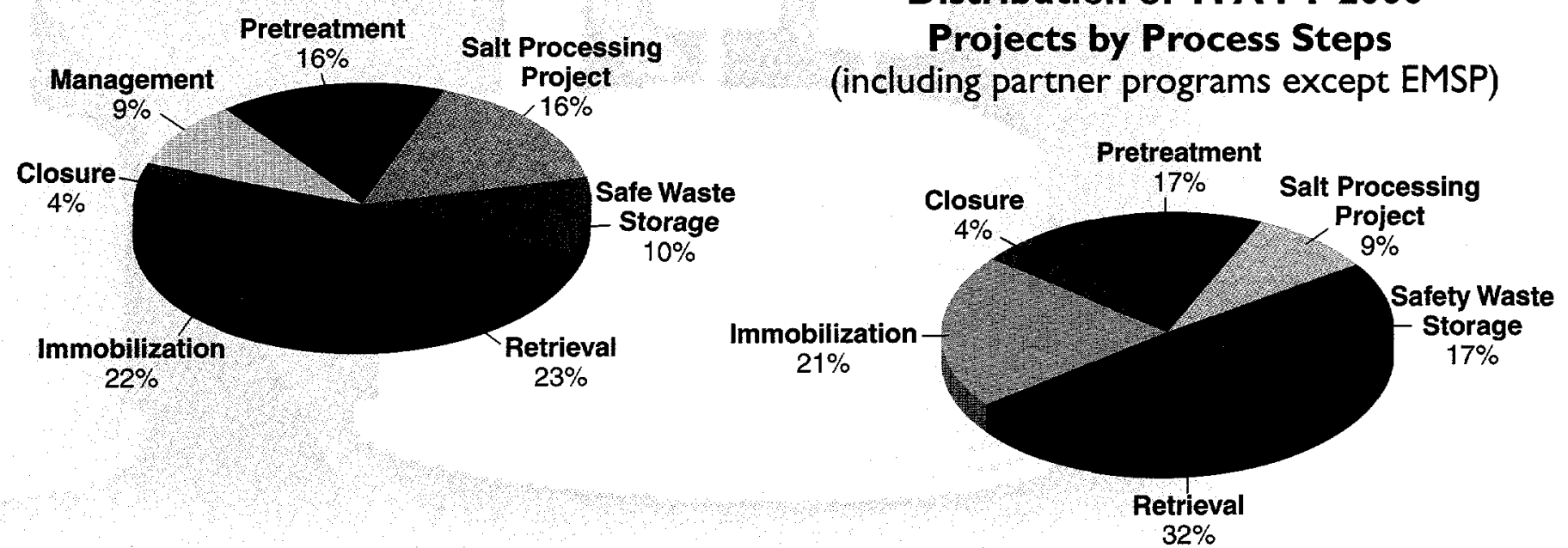

\section{EMSP Research Projects}

\begin{tabular}{|c|c|c|c|}
\hline 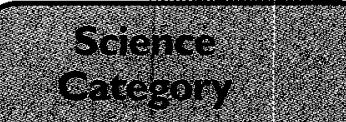 & $\begin{array}{l}\text { - provi } \\
\text { mpojects }\end{array}$ & $\begin{array}{l}\text { Total runding } \\
(\mathrm{S} 1 \mathrm{~S})\end{array}$ & $\begin{array}{l}\text { Sites Needs } \\
\text { Ariressed }\end{array}$ \\
\hline Actinide Chemistry & 4 & 1,423 & Hanford, SRS \\
\hline $\begin{array}{l}\text { Analytical Chemistry } \\
\text { and Instrumentation }\end{array}$ & 7 & 1,902 & Hanford \\
\hline Engineerng Science & 4 & 1,009 & Hanford \\
\hline Geochemistry & 1 & 330 & Hanford \\
\hline Iydrogeology & 1 & 378 & Hanford, NEEL \\
\hline Inorganic Chemistry & 2 & 711 & Hanford, SRS \\
\hline Material Science & 8 & 1,797 & Hanford, INEEL, SI \\
\hline Separations Chemistry & 10 & 2,542 & Hanford, SRS \\
\hline
\end{tabular}




\begin{tabular}{|c|c|c|c|c|}
\hline $\begin{array}{l}\text { Process } \\
\text { Step }\end{array}$ & $\begin{array}{c}\text { Project Title } \\
\text { (Technical Response ID) }\end{array}$ & $\begin{array}{l}\text { Technologies Used in Project } \\
\text { (Tech ID) }\end{array}$ & $\begin{array}{c}\text { Site } \\
\text { (Site Need ID) }\end{array}$ & $\begin{array}{l}\text { Total } \\
\text { Funding (\$K) }\end{array}$ \\
\hline \multirow{5}{*}{$\frac{\frac{9}{0}}{\frac{2}{8}}$} & Alternative Filtration Technology $(99071)$ & Alternative Fitration Technology $(209)$ & $\begin{array}{l}\text { SRS (SR99-2027) } \\
\text { INEEL (ID-2.1.27) }\end{array}$ & 780 \\
\hline & $\begin{array}{l}\text { Hanford/INEEL Fluidic Sampler and LDUA } \\
\text { Sampler (99046) }\end{array}$ & $\begin{array}{l}\text { Nested Fixed Depth Fluidic Sampler (2119) } \\
\text { Heel Sampling End Effector (2386) }\end{array}$ & $\begin{array}{l}\text { Hanford (RL-WT09) } \\
\text { INEEL (D-2.1.44) } \\
\text { INEEL (ID-2.1.43) } \\
\text { INEEL (ID-2.1.26) }\end{array}$ & 1,080 \\
\hline & $\begin{array}{l}\text { Tank Inspection and Integrity Techniques for } \\
\text { Hanford, SRS, ORR, and INEEL }(99075)\end{array}$ & $\begin{array}{l}\text { TSAFT Ultrasonic lnspection } \\
\text { Improvements ( } 3094 \text { ) } \\
\text { ORNL MVST Camera System (3095) }\end{array}$ & $\begin{array}{l}\text { SRS (SR99-2035) } \\
\text { WNEEL (ID-2,1,20) } \\
\text { ORNL (OR-TK-01) } \\
\text { Hanford (RL-WT022) } \\
\text { Hanford (RL-WT05) }\end{array}$ & 419 \\
\hline & $\begin{array}{l}\text { High-Level Waste Tank Corrosion Control and } \\
\text { Monitoring (99043) }\end{array}$ & $\begin{array}{l}\text { Raman Sensor for Tank Corrosion (2015) } \\
\text { Chemistry Monitoring } \\
\text { Electrochemical Noise Corrosion Monitor } \\
\text { System (1985) }\end{array}$ & $\begin{array}{l}\text { Hanford (RL-WTO4) } \\
\text { SRS (SR99-2045) } \\
\text { ORNL (OR-TK-OI) }\end{array}$ & 789 \\
\hline & $\begin{array}{l}\text { Slurry Transfer and Tank Waste Mixing } \\
\text { Monitors (99078) }\end{array}$ & $\begin{array}{l}\text { Dual Conolis Meters for Pipeline Sturry } \\
\text { Monitoring }(2970) \\
\text { Comparative Testing of Pipeline Slurry } \\
\text { Monitors (1547) }\end{array}$ & $\begin{array}{l}\text { SRS (SR99-2044) } \\
\text { ORNL (OR-TK-04) } \\
\text { SRS (SR99-2037) }\end{array}$ & 400 \\
\hline \multirow{5}{*}{$\frac{\overline{\frac{5}{3}}}{\mathrm{~d}}$} & Tank Heel Retrieval Technology (99067) & $\begin{array}{l}\text { Light Duty Utility Arm (LDUA) (85) } \\
\text { Confined Siuicing End Effector (CSEE) (8|2) } \\
\text { Pulsed Air Mixer (1510) } \\
\text { In-Tank Waste Retrieval (20|2) } \\
\text { Houdini-ll Remotely Operated Vehicle } \\
\text { System (2085) } \\
\text { Pipe Cutting and Isolation System (2093) } \\
\text { Heel Retrieval for SRS (2097) } \\
\text { Tank Waste Dislodging and Conveyance } \\
\text { System (21|6) } \\
\text { Enhanced Sluicing (21 I7) } \\
\text { Flygt Mixer (2232) } \\
\text { Disposal Crawler (2366) } \\
\text { Russian Pulsating Mixer Pump (2370) } \\
\text { Gunite Scarifying End Effector (2384) } \\
\text { AWRS (2948) } \\
\text { SRS Chemical Cleaning (2967) }\end{array}$ & $\begin{array}{l}\text { WDP (OH-W-905) } \\
\text { SRS (SR99-2037) } \\
\text { Hanford (RL-WT064) } \\
\text { Hanford (RL-WT027) } \\
\text { ORNL (OR-TK-02) } \\
\text { INEEL (ID-2.I.47) }\end{array}$ & 4.753 \\
\hline & $\begin{array}{l}\text { Horizontal and Smal Tank Sludge Mixing and } \\
\text { Mobilization }(99082)\end{array}$ & $\begin{array}{l}\text { Moble Retrieval Systen }(2947) \\
\text { SRS Small Tank Retrieval }(3108)\end{array}$ & $\begin{array}{l}\text { SRS }(S R 99-3022) \\
\text { ORNL }(\mathrm{ORTK}-03) \\
\text { ORNLL }(\mathrm{ORTK}-02)\end{array}$ & 68 \\
\hline & $\begin{array}{l}\text { Waste Transfer Line Plugging Prevention and } \\
\text { Unplugging Methods (99076) }\end{array}$ & Pipeline Unplugging (2367) & $\begin{array}{l}\text { SRS (SR99-2039) } \\
\text { SRS (SR99-2035) } \\
\text { Hanford (RL-WTO23) } \\
\text { ORNL (OR-TK-02) }\end{array}$ & 1,365 \\
\hline & Transfer Pumping (99059) & SRS Pump Tank Mixer (2408) & $\begin{array}{l}\text { Hanford (RL-WTO60) } \\
\text { SRS (SR99-2041) } \\
\text { SRS (SR99-2037) } \\
\text { Hanford (RL-WTO62) } \\
\text { SRS (SR99-2028) }\end{array}$ & 674 \\
\hline & $\begin{array}{l}\text { Hanford/SRS Waste Mixing and } \\
\text { Mobilization (99059) }\end{array}$ & $\begin{array}{l}\text { SRS Pump Tank Mixer (2408) } \\
\text { Variable Depth Transfer Pump (3091) }\end{array}$ & $\begin{array}{l}\text { Hanford (RL-WT060) } \\
\text { SRS (SR99-2-4I) } \\
\text { SRS (SR99-2037) } \\
\text { Hanford (RL-WT062) } \\
\text { SRS (SR99-2028) }\end{array}$ & 674 \\
\hline
\end{tabular}




\begin{tabular}{|c|c|c|c|c|}
\hline $\begin{array}{l}\text { Process } \\
\text { Step }\end{array}$ & $\begin{array}{c}\text { Project Title } \\
\text { (Technical Response ID) }\end{array}$ & $\begin{array}{l}\text { Technologies Used in Project } \\
\text { (Tech ID) }\end{array}$ & $\begin{array}{c}\text { Site } \\
\text { (Site Need ID) }\end{array}$ & $\begin{array}{c}\text { Total } \\
\text { Funding (\$K) }\end{array}$ \\
\hline$\frac{18}{6.8}$ & $\begin{array}{l}\text { Remote Systems for Pit Operations and } \\
\text { Maintenance }(9052) \text {. }\end{array}$ & $\begin{array}{l}\text { Tank Rser Pit Decontamination } \\
\text { System }(2195)\end{array}$ & $\begin{array}{l}\text { Hanford (RLWIOL) } \\
\text { ORN }(O R T K-02) \\
\text { SRS }(S R 99-2040) \\
\text { SRS }(S R T 9203) \\
\text { SRS }(S R 99-2037)\end{array}$ & 1,300 \\
\hline & Hanford Tank Waste Chemistry (99054) & Hanford Waste Transfer/Solids Formation (3079) & Hanford (RL-WTO23) & 1,375 \\
\hline & Solid-Liquid Separations MVST (99084) & Crossflow Fitration (350) & $\begin{array}{l}\text { ORNL (OR-TK-05) } \\
\text { ORNL (OR-TK-OA) }\end{array}$ & 150 \\
\hline & $\begin{array}{l}\text { Decon Process Waste Volume } \\
\text { Reduction ( } 99003 \text { ) }\end{array}$ & $\begin{array}{l}\text { Decontamination Methods } \\
\text { Development (TBD) }\end{array}$ & INEEL (ID-2.I.16) & 200 \\
\hline & $\begin{array}{l}\text { INEEL Integrated Radionuclide Separations } \\
\text { Process }(99001)\end{array}$ & $\begin{array}{l}\text { INEEL HIW Processing (206) } \\
\text { TRUEX SREX (347) } \\
\text { CS Removal using AMP-PAN (2968) }\end{array}$ & $\begin{array}{l}\text { INEEL (DD-2.1.53) } \\
\text { NEEE }(\mathrm{D}-2.1 .54) \\
\text { INEE }(\text { ID } 2.1 .55) \\
\text { INEEL (ID-2.1.06) }\end{array}$ & 1,150 \\
\hline & ASTD Evaporator/Treatment (99086) & $\begin{array}{l}\text { Out of Tank Evaporator (20) } \\
\text { Cesium Removal Using Crystalline } \\
\text { Silicotitanate (2I) }\end{array}$ & ORNL (OR-TK-II) & 806 \\
\hline & Hanford Tank Waste Chemistry (99054B) & Saltcake Dissolution (1989) & $\begin{array}{l}\text { Hanford (RL-WTO63) } \\
\text { Hanford (RL-WTO23) }\end{array}$ & 475 \\
\hline & Salt Processing Project ( 99070$)$ & $\begin{array}{l}\text { Cs Removal using Crystalline Silicotitanate } \\
\text { (CST) (21) } \\
\text { Advanced Integrated Solvent Extraction } \\
\text { Systems (204) } \\
\text { Tetraphenyborate (TPB) (3088) } \\
\text { Monosodium Titanate (MST) (3089) }\end{array}$ & SRS (SR99-2034) & 6992 \\
\hline & $\begin{array}{l}\text { Specify and Enhance Design of HLW Glass } \\
\text { Meiters }(99068)\end{array}$ & $\begin{array}{l}\text { NEEL Melter Development ( } 8078 \text { ) } \\
\text { DWPF Melter Pounng Enhancements (2092), } \\
\text { New Metter Technology ( } 3075 \text { ) } \\
\text { Next Generation Melter Development ( } 307 \text { ) }\end{array}$ & $\begin{array}{l}\text { SRS }(S R 992036) \\
\text { NEEL }(D-2 / 57) \\
N E E L(D-2158)\end{array}$ & 1,475 \\
\hline & Improve Waste Loading in HLW Glass (99073) & $\begin{array}{l}\text { High-Activity Waste Forms and } \\
\text { Processes (2009) }\end{array}$ & $\begin{array}{l}\text { INEEL (ID-2.|.58) } \\
\text { Hanford (RL-WTO6) } \\
\text { SRS (SR99-2032) }\end{array}$ & 1,790 \\
\hline & $\begin{array}{l}\text { Conditioning and Immobilization of } \\
\text { Low-Activity Waste }(99019)\end{array}$ & Low-Activty Waste Forms (82) & 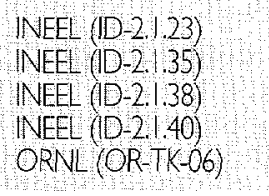 & 1,544 \\
\hline & $\begin{array}{l}\text { Remote Disassembly of HLW Melters and } \\
\text { Other Processing Equipment ( } 99077)\end{array}$ & $\begin{array}{l}\text { Virification Expended Material Processing } \\
\text { System (2383) } \\
\text { Remote Size Reduction System (2082) } \\
\text { Remote Technologies for Tank Waste Processing } \\
\text { Equipment Maintenance and Disposal (2942) } \\
\text { Melter Glass Removal Methods (3098) }\end{array}$ & $\begin{array}{l}\text { SRS (SR99-2040) } \\
\text { WDP (OH-W-903) }\end{array}$ & 1,185 \\
\hline 8 & $\begin{array}{l}\text { Testing of Prediction of Long-Term Waste Glass } \\
\text { Performance (99048) } \\
\text { Idaho Tank WM-182 Closure } \\
\text { Demonstration (99023) }\end{array}$ & $\begin{array}{l}\text { Low-Activity Waste Forms (82) } \\
\text { Product Acceptance Testing (2094) } \\
\text { Tank Closure Performance } \\
\text { Objectives (2369) }\end{array}$ & $\begin{array}{l}\text { Hanford (RL-WT066) } \\
\text { Hanford (RL-WTOI5) } \\
\text { INTERNATIONAL } \\
\text { INEEL (ID-2.l.48) } \\
\text { INEEL (ID-2.I.47) } \\
\text { INEEL (ID-2.I.46) } \\
\text { INEEL (ID-2.l.42) } \\
\text { INEEL (ID-2.l.39) } \\
\text { INEEL (ID-2.I.45) } \\
\text { WWD (OH-WW-904) } \\
\text { SRS (SRO9-3022) } \\
\text { ORNL (OR-TK-09) }\end{array}$ & 1,200 \\
\hline
\end{tabular}


Tanks Focus Area Program Lead

Ted Pietrok

(509) 372-4546

Tanks Focus Area Program Manager

Kurt Gerdes

(301) 903-7289

Tanks Focus Area Web Site

http://www.pnl.gov/tfa

Office of Science and Technology

http://ost.em.doe.gov 